ROCZNIKI FILOZOFICZNE

Tom LXVIII, numer $4-2020$

DOI: https://doi.org/10.18290/rf20684-7

MAREK SŁOMKA

\title{
ANTYEWOLUCYJNY KREACJONIZM \\ WE WSPÓŁCZESNEJ POLSCE I JEGO WPŁYW \\ NA EDUKACJĘ RELIGIJNA
}

\begin{abstract}
WSTĘP
Poza analizą poszczególnych aspektów problematyki ewolucjonizm kreacjonizm, ważnym jej wymiarem pozostaje ładunek światopoglądowy, którego siła ujawnia się między innymi w debacie publicznej, dotykającej ważnych sfer życia społecznego, m.in. edukacji szkolnej. Kwestie te są przedmiotem intensywnych sporów zwłaszcza w tych środowiskach czy krajach, w których religia stanowi ważnym składnik kultury, nieredukowalny do sfery prywatnych poglądów. Można to zaobserwować również w Polsce, gdzie napięcie pomiędzy otwarciem na nauki przyrodnicze a uwzględnieniem koncepcji teologicznych oraz religijnych pojawia się wyraźnie $\mathrm{w}$ treści wielu publikacji, także popularnonaukowych i pozanaukowych.

Powyższy stan rzeczy jest godnym uwagi polem badań filozoficznych. Skupiają się one zwykle na objaśnianiu stosowanej terminologii oraz analizie proponowanych rozwiązań z punktu widzenia ich wewnętrznej koherentności i zborności z aktualną wiedzą fillozoficzną, teologiczną czy przyrodniczą. W niniejszym tekście przeanalizuję tezy stawiane przez polskich antyewolucyjnych kreacjonistów, które w ostatnich latach zostały wyrażone nie tylko w publikacjach naukowych, ale także w różnych środkach społecznej komunikacji oraz w publicznie prowadzonych dyskusjach, stanowiących istotny aspekt omawianej dziedziny ${ }^{1}$.
\end{abstract}

Ks. dr hab. Marek SŁomka - Katolicki Uniwersytet Lubelski Jana Pawła II, Instytut Filozofii, Katedra Filozofii Religii; adres do korespondencji: Wydział Filozofii, Al. Racławickie 14, 20-950 Lublin; email: mslomka@kul.pl; ORCID: https://orcid.org/0000-0001-5951-6587.

${ }^{1}$ Świadomie pomijam prezentację poszczególnych etapów kształtowania się antyewolucyjnego kreacjonizmu w Polsce, choć wiele z nich stanowi ważny punkt odniesienia do zrozumienia 
Celem artykułu jest określenie głównych składowych antyewolucyjnego kreacjonizmu oraz uchwycenie mechanizmów myślenia, które prowadzą do wewnętrznej niespójności formułowanych koncepcji, a także niezgodności z wiedzą przyrodniczą, filozoficzną i teologiczną ${ }^{2}$. Pokażę też, jak pojawiające się w tej dziedzinie błędy i stereotypy wpływają na przekaz treści religijnych, zawartych zwłaszcza w opublikowanych w ostatnich latach podręcznikach do katechezy szkolnej w Polsce.

\section{TYLKO TEORIA CZY SZKODLIWA IDEOLOGIA?}

Hasło „to tylko teoria” tak mocno zakorzeniło się w przekazie pewnych treści, że jego stosowanie znacznie wykracza poza ramy sporu ewolucjonizm-kreacjonizm ${ }^{3}$. Jednak przede wszystkim w kontekście refleksji nad teorią ewolucji można dostrzec napięcia wynikające $\mathrm{z}$ przeciwstawiania teorii faktom oraz obniżania rangi odkryć naukowych minionych dziesięcioleci. Mimo że filozofowie nauki od wielu lat wskazują na zasadniczą różnicę w znaczeniu terminów używanych w języku potocznym i naukowym ${ }^{4}$, antyewolucyjni kreacjoniści często powtarzają, że teoria ewolucji to tylko teoria, a nie wartościowa koncepcja naukowa, ewolucjonizm zaś nie ma wiele wspólnego z faktami. W takim ujęciu przez teorię rozumie się hipotezę lub spekulację a ewolucjonizm niejednokrotnie utożsamia się z redukcjonistyczną doktryną filozoficzną oraz światopoglądem materialistycznym ${ }^{5}$.

We wstępie redakcyjnym do książki pt. Kosmos $i$ człowiek, wydanej w ramach pallotyńskiej kolekcji Communio, autorzy akcentują, że opublikowane tam kolejno wyniki badań specjalistów z różnych dziedzin nauki przemawiają za brakiem jakichkolwiek merytorycznych podstaw do przyjęcia ewolucjonizmu. Ma on być poglądem propagowanym tendencyjnie, przyj-

specyfiki współczesnych ujęć w tym zakresie. W celu prześledzenia historii recepcji darwinizmu w Polsce i rozpoznania tego, jakie czynniki (np. socjologiczne, instytucjonalne) decydowały o rozwoju tendencji antyewolucyjnych w kolejnych latach, odsyłam czytelnika do strony internetowej Pawła Polaka (http://polak.wikidot.com/monograf:recepcja-teorii-ewolucji-w-polsce), zawierającej linki do tekstów (dostęp 14.08.2020).

${ }^{2} \mathrm{~W}$ artykule biorę pod uwagę wiedzę z zakresu teologii katolickiej, choć wiele omawianych przez mnie kwestii należy do wspólnego dziedzictwa wszystkich denominacji chrześcijańskich.

${ }^{3}$ Przykładem jest portal internetowy www.totylkoteoria.pl.

${ }^{4}$ Por. Zygmunt Hajduk, Ogólna metodologia nauk (Lublin: Wydawnictwo KUL, 2001), 204.

${ }^{5}$ Wnikliwe analizy terminologiczne dotyczące teorii ewolucji i ewolucjonizmu zawarte są w: Józef Zon, „Ewolucja i ewolucjonizm”, w: Dydaktyka filozofii, t. 7, Filozofia przyrody, red. Stanisław Janeczek et al. (Lublin: Wydawnictwo KUL, 2013), 87-113. 
mowanym łatwo, pochopnie i „na wiarę” jako fakt rzekomo udowodniony, co sprawia, że nie warto budować na nim wiedzy religijnej o człowieku i świecie ${ }^{6}$. Co ciekawe, niektóre artykuły zawarte $w$ tej publikacji traktują paradygmat ewolucyjny jako podstawowy punkt odniesienia w różnych dziedzinach współczesnej nauki ${ }^{7}$.

W tekście opublikowanym w jednym z katolickich czasopism, Mirosław Rucki podkreśla, że „cała teoria Darwina ze wszystkimi jej modyfikacjami bazuje na braku danych, a nie na naukowo potwierdzonych faktach" ${ }^{8}$. Z kolei w artykule pt. „Nauka na służbie ideologii” Maciej Giertych stwierdza, że ewolucjonizm nie należy do obszaru nauki, lecz spekulacji. Ewolucjonizm przedstawiany jest wręcz jako ideologia, którą należy ocenić analogicznie do marksizmu i freudyzmu. Wszystkie trzy wymienione dziedziny wiedzy są według niego pozbawione wartości i ,plączą się po instytucjach naukowych nie będąc naukami”" . W tej samej publikacji czytamy: „Ewolucja to tylko teoria, teoria naukowa, która wymaga udowodnienia" $"$.

Niektórzy kreacjoniści nie tylko traktują teorię ewolucji w kategoriach hipotezy, ale nawet odmawiają możliwości weryfikacji danych w tym zakresie. Andrzej Maryniarczyk pisze, że tezy „teorii ewolucji dotyczące zarówno powstawania gatunków, jak i powstania życia w ogóle, a człowieka w szczególności, jak również cała teoria ewolucjonizmu (jako teoria uniwersalna) nie są empirycznie weryfikowane. Są to tylko hipotezy, które próbuje się empirycznie uprawdopodobnić (wystarczy wspomnieć, że do dzisiaj nie ma empirycznie potwierdzalnego dowodu na istnienie form przejściowych pomiędzy światem zwierząt a ludzi, że nie ma zweryfikowanego empirycznie przejścia z materii nieożywionej w ożywioną itd.)" ${ }^{\text {"11 }}$.

Antyewolucyjni kreacjoniści chętnie przeciwstawiają prawdziwość niekwestionowalnych faktów względem hipotetyczności teorii naukowych. Należy w tym kontekście przypomnieć, że teorie naukowe ze swej natury za-

\footnotetext{
${ }^{6}$ Stanisław Stancel i in., red., Kosmos i czlowiek (Poznań: Pallottinum, 1989), 5.

${ }^{7}$ Por. np. Juan Luis de LA PEÑA, „Umysły, mózgi, maszyny”, tłum. Małgorzata Tryc-Ostrowska, w: Stancel i in., Kosmos i czlowiek, 156-170.

${ }^{8}$ Mirosław RucKI, „Uczciwie o teorii ewolucji”, Miłujcie się! 5 (2009), dostęp 20.08.2020, http://www.jp2w.pl/pl/37921/41030/Uczciwie_o_teorii_ewolucji.html.

${ }^{9}$ Maciej Giertych, „Nauka na służbie ideologii”, Opoka w kraju 46 (wrzesień 2003): 8, dostęp 20.08.2020, http://opoka.giertych.pl/owk46.htm.

${ }^{10}$ Tamże, 7.

${ }^{11}$ Andrzej MaryniarczyK, „Dlaczego kreacjonizm?” w: Ewolucjonizm czy kreacjonizm (Przyszłość cywilizacji Zachodu), red. Piotr Jaroszyński (Lublin: Fundacja Lubelska Szkoła Filozofii Chrześcijańskiej, 2008), 49-50; por. też: Andrzej MARYNIARCZYK, Dlaczego stworzenie „ex nihilo”. Teoria metafizycznego kreacjonizmu (Lublin: Polskie Towarzystwo Tomasza z Akwinu, 2018), 111.
} 
wierają elementy hipotetyczne, podległe zmianom, doskonaleniu lub odrzuceniu, zaś wszystkie fakty są w jakiś sposób obciążone teoretycznie. Bez wcześniejszego uznania, przynajmniej implicite, określonych założeń teoretycznych niemożliwe jest stwierdzenie jakiegokolwiek faktu. Truizmem jest współcześnie stwierdzenie, że nie istnieją czyste (resp. nagie) fakty. Przeciwstawienie faktów teoriom jest metodologicznym błędem. Na poziomie refleksji przed-teoretycznej niemożliwa jest konstatacja żadnych faktów. Warto jednocześnie zauważyć, że samo określenie „fakt” pochodzi od łacińskiego facio, co znaczy „czynię, działam”. Źródłosłów zatem podkreśla rolę podmiotowych uwarunkowań w określaniu faktów ${ }^{12}$.

Akcentowanie spekulatywnego wymiaru oraz hipotetyczności teorii naukowych w celu podważania ich doniosłości występuje także w kontekście przeciwstawiania nauk przyrodniczych względem teologii. Ta ostatnia miałaby być wolna od błędów i posiadać charakter wiedzy pewnej. „W klasycznym chrześcijańskim rozumieniu” - stwierdza Michał Chaberek — „to teologia daje wiedzę pewną, nauki natomiast są zmienne i omylne"13. Łagodząc najmocniejsze deklaracje w omawianym zakresie, Chaberek podkreśla w innym miejscu, że „twierdzenia teologii są bardziej pewne niż twierdzenia nauk przyrodniczych"14.

Hipotetyczność nauk empirycznych bywa też uwypuklana przez filozofów jako argument za wyróżnieniem pod względem wartości poznawczej metafizyki, rzekomo wolnej od analogicznych niedoskonałości ${ }^{15}$. Zestawienie przyrodniczych badań $\mathrm{z}$ filozoficznym poszukiwaniem ostatecznych przyczyn zjawisk ma prowadzić do przekonania, że doxa i episteme to całkowicie rozłącznie zbiory danych, zaś granicę między nimi da się w prosty sposób określić i przebiega ona pomiędzy wymienionymi dyscyplinami. Pozostaje to przykładem myślenia życzeniowego, które nie uwzględnia hipotetycznych czy spekulatywnych elementów, koniecznych zarówno przy formułowaniu koncepcji przyrodniczych, jak i wielu teorii filozoficznych oraz teologicznych. Poza tym niejednokrotnie pomijana jest kwestia stopnia prawdopodobieństwa teorii naukowych, a ogólność teorii z zakresu nauk

\footnotetext{
${ }^{12}$ Por. Marek SŁomKA, Ewolucjonizm chrześcijański o pochodzeniu człowieka (Lublin: Gaudium, 2004), 36-37.

${ }^{13}$ Michał Chaberek, Tomasz Rowiński, Stworzenie czy ewolucja. Dylemat katolika (Warszawa: Fronda, 2014), 56.

${ }^{14}$ Tamże, 226.

${ }^{15}$ Takie stanowisko wyrażał np. Tomasz Duma w wykładzie pt. „Istnienie a rzeczywistość. Rozważania z podstaw rozumienia rzeczywistości”, zaprezentowanym podczas 61. Tygodnia Filozoficznego na KUL 8 kwietnia 2019 r. (https://www.youtube.com/watch?v=oMWG7W33KyI).
} 
humanistycznych przeciwstawiana jest szczegółowym rozwiązaniom proponowanym przez nauki przyrodnicze. Rzecz jasna, przy pewnym stopniu ogólności konstatacje metafizyczne przyjmują postać zdań, którym trudno odmówić prawdziwości, np.: byt konieczny jest ontycznie doskonalszy od bytu przygodnego. Nie można tego jednak uznać za dowód wyższości filozofii nad naukami przyrodniczymi.

Niektóre deklaracje polskich antyewolucjonistów lekceważą nie tylko istotne dystynkcje z zakresu filozofii nauki, ale i podstawowe dane naukowe dotyczące datowania poszczególnych etapów rozwoju wszechświata. W tekście „Meandry sporów o pochodzenie” czytamy: „Ewolucja nie jest żadnym faktem. Nie istnieją dowody na jej rzecz, to zwykła hipoteza. Nie było żadnych małpoludów. Ziemia nie liczy sobie miliardów lat" ${ }^{\text {"16 }}$. Członkowie założonego w 1993 r. przez autora powyższych słów Mieczysława Pajewskiego Polskiego Towarzystwa Kreacjonistycznego (Polish Anti-Macroevolution Organisation) uznają teorię ewolucji biologicznej za błędny paradygmat naukowy i podkreślą, że dane doświadczenia nie potwierdzają makroewolucji ${ }^{17}$, zaś upowszechnienie się ewolucjonizmu w naukach przyrodniczych doprowadziło do kryzysu wiary w Boga i moralności we współczesnym świecie ${ }^{18}$.

W najbardziej radykalnych wywodach z zakresu antynaukowego kreacjonizmu brakuje związków wynikania logicznego, a teoria ewolucji przedstawiana jest jako fundamentalne zagrożenie dla religii i kultury. W artykule zatytułowanym „Wpływ teorii ewolucji Karola Darwina na moralność, życie i pojmowanie świata" Łukasz Sowa pisze, że do połowy XIX w. powszechnie uznawano pochodzenie świata od wszechmocnego Boga, który stworzył wszechświat, życie na ziemi oraz człowieka. Podstawami wiary, jego zdaniem, zachwiała koncepcja przypadkowej genezy życia z bezładnej materii. Od czasu powstania tej teorii zachodzi zatem konieczność dokonania wyboru pomiędzy kreacjonizmem a ewolucjonizmem, bo ten ostatni przedstawia wszechświat nie jako dzieło Stwórcy, ale jako model ślepo ukształtowanej materii. Według autora tekstu ewolucja godzi w fundamenty Kościoła ${ }^{19}$.

\footnotetext{
${ }^{16}$ Mieczysław PAJEwSKi, „Meandry sporów o pochodzenie (cz. 5)”, Idź pod prąd, nr 13 (sierpień 2005): 9.

17 „Pytania o prawdę. Z dr Eugeniuszem Moczydłowskim, prezesem Polskiego Towarzystwa Kreacjonistycznego rozmawia Jacek Słaby”, Magazyn Chrześcijański CEL 7, nr 4 (2006): 28-30.

${ }^{18}$ PAJEWSKI, Meandry sporów o pochodzenie, 8-9.

${ }^{19}$ Łukasz Sowa, „Wpływ teorii ewolucji Karola Darwina na moralność, życie i pojmowanie świata”, Communitas 30, nr 1 (2008): 49. Por. też: Józef F. KRAwCzyK, Człowiek nie zaistniat przez przypadek - przegrałeś Darwinie! (Sandomierz: Wydawnictwo Diecezjalne, 2003), 111;
} 
W drugiej części artykułu Sowa stwierdza, że w debacie naukowej i edukacji od lat faworyzuje się ewolucjonizm, nadając mu charakter dogmatyczny $^{20}$. Poglądy Darwina stanowią zagrożenie dla cywilizacji, czego przykładem była II wojna światowa. Przyczyną degradacji kultury jest zredukowanie człowieka poprzez teorię jego zwierzęcego pochodzenia do instynktów posiadania, dominowania czy przetrwania. Dowiadujemy się, że ewolucja „wykreowała obraz niereformowalnego, okrutnego, zdradliwego, egoistycznego, rządnego, władzy i pieniędzy Homo sapiens" ${ }^{\prime 2}$.

\section{NAUKOWE OSZUSTWA \\ I PROBLEM EMPIRYCZNYCH ŚWIADECTW}

Antyewolucyjni kreacjoniści chętnie uwypuklają wszelkie wątpliwości związane $\mathrm{z}$ teorią ewolucji, skrupulatnie kolekcjonując dane mające świadczyć o problemach przyrodników z jej obroną. Działania takie stanowią podstawowy komponent tzw. strategii klina (ang. wedge strategy), społecznej akcji zapoczątkowanej przez amerykański Discovery Institute (Seattle, WA), propagujący teorię inteligentnego projektu. Według jednego z jej czołowych zwolenników, Philipa E. Johnsona, współczesna nauka tylko pozornie wygląda jak solidny pień i wystarczy znaleźć drobne pęknięcie, wbić w nie klin oraz wytrwale stukać, a pień na pewno pęknie. Trzeba zatem skupić się na wyszukiwaniu rys w teorii ewolucji ${ }^{22}$.

Stosowanie takiej strategii przez antyewolucyjnych kreacjonistów widać wyraźnie na polu antropogenezy. Mimo że już w latach pięćdziesiątych dwudziestego stulecia wiadomo było o mistyfikacji znaleziska tzw. człowieka z Piltdown, do dziś bywa ono traktowane jako kompromitacja argumentu za istnieniem ogniw pośrednich między Homo sapiens a jego ewolucyjnymi po-

Marek SŁOMKA, „Antynaukowy kreacjonizm jako negacja teistycznego ewolucjonizmu”, w: Naukowy a religijny obraz początku wszechświata i człowieka. Perspektywy dialogu, red. Jacek Golbiak, Karol Jasiński, Wojciech Kotowicz (Olsztyn: Wydawnictwo UWM, 2015), 119.

${ }^{20}$ Por. SowA, Wplyw teorii ewolucji, 50.

${ }^{21}$ Tamże, 51. Z jednej strony, można zbanalizować wymowę tego tekstu, podkreślając, że jego autorem jest student, w tym przypadku alumn jednego z polskich seminariów duchownych. $\mathrm{Z}$ drugiej strony, warto zauważyć, że — jak czytamy we wstępie — tekst stanowi fragment pracy proseminaryjnej z filozofii pt. Teoria ewolucji - stwierdzenie faktu czy hipoteza? Dzieje myśli Karola Darwina. Powstaje więc zasadnicze pytanie o wpływ promotora na kształt tej pracy oraz o poziom prowadzonej przez niego edukacji filozoficznej w placówce kształcącej przyszłych księży, będącej w sferze studiów częścią wydziału teologicznego jednej z polskich uczelni.

${ }^{22}$ Elżbieta Olender, „Amerykańska wojna z Darwinem”, House of Books/Dom Książki, 24. 03.2006, dostęp 18.08.2020, https://www.domksiazki.com/press_det.aspx?id=51. 
przednikami. Jako dowód na brak form przejściowych pomiędzy człowiekiem a zwierzętami niższymi przytacza się także kontrowersyjne historie odkryć Homo erectus pekinensis, człowieka z Nebraski i człowieka z Heidelbergu ${ }^{23}$.

Kwestia pochodzenia człowieka pozostaje jednym z kluczowych elementów przekazu wielu antyewolycyjnych kreacjonistów, którzy definitywnie wykluczają możliwość ciągłości przyrodniczego rozwoju w tym zakresie. Chaberek twierdzi, że materiał empiryczny dowodzący wspólnego pochodzenia człowieka i małp człekokształtnych jest „ubogi i bardzo niejednoznaczny” ${ }^{24}$, „istnienie wielu ogniw pośrednich jest założeniem, a nie wnioskiem z badań” 25 , zaś „hominidy istnieją tylko w wyobraźni paleontologów”, gdyż w „rzeczywistości mamy do czynienia z różnymi rasami ludzi” ${ }^{26}$.

Kwintesencją wyżej przywołanych konstatacji jest ogólniejsze przekonanie Chaberka, że przyrodnicy ślepo wierzą w ewolucję gatunków ${ }^{27}$. Jego zdaniem, współcześnie ,wiemy, że poszczególne gatunki pojawiały się jako w pełni rozwinięte" ${ }^{28}$, zaś obserwując przyrodę widzimy, że „nowe gatunki pojawiają się nagle, jakby znikąd, istnieją przez wiele lat, a później giną"29. Trzeba zauważyć, że takie tezy nie mają merytorycznego uzasadnienia w świetle obecnej wiedzy naukowej, wiele zaś cenionych publikacji przedstawia różne mechanizmy specjacji ${ }^{30}$. Współcześni przyrodnicy przedstawiają też wiele danych empirycznych potwierdzających ewolucyjny charakter powstawania gatunków, wymieniając świadectwa istnienia form pośrednich, zarówno na granicy między przyrodą nieożywioną a ożywioną, jak i pomiędzy zwierzętami niższymi a człowiekiem ${ }^{31}$.

\footnotetext{
${ }^{23}$ Por. KrawCZYK, Człowiek nie zaistnial przez przypadek, 28-30; MARYNIARCZYK, Dlaczego stworzenie ,ex nihilo”, 109-110.

${ }^{24}$ CHABEREK, Stworzenie czy ewolucja, 72.

${ }^{25}$ Tamże, 75.

${ }^{26}$ Tamże, 78.

${ }^{27}$ Tamże, 100.

${ }^{28}$ Tamże, 114.

${ }^{29}$ Tamże, 143.

${ }^{30}$ Sara VIA, „Natural selection in action during speciation”, Proceedings of the National Academy of Sciences of the United States of America 106 (2009): 9939-9946 (suplement 1); Jason M. BAKER, „Adaptive speciation. The role of natural selection in mechanisms of geographic and nongeographic speciation”, Studies in History and Philosophy of Science Part C: Studies in History and Philosophy of Biological and Biomedical Sciences 36, nr 2 (2005): 303-326; Rebecca J. SAfran, Patrik Nosil, „Speciation. The Origin of New Species”, Nature Education Knowledge 3 (2012): 17; Jerry A. Coyne, H. Allen Orr, Speciation (Sunderland, MA: Sinauer, 2004); Douglas J. FutuYma, Ewolucja (Warszawa: Wydawnictwo UW, 2008), 384-408.

${ }^{31}$ Tom Fenchel, The Origin and Early Evolution of Life (Oxford: OUP, 2002); Robert M. Hazen, Genesis. The Scientific Quest for Life's Origin (Washington, DC: Joseph Henry Press,
} 


\section{KOSMOGENEZA, BIOGENEZA I FILOGENEZA} POZA NAUKA

Maryniarczyk apeluje, by dyskusję na temat początków świata i życia prowadzić na płaszczyźnie metafizyki ${ }^{32}$, dodając, że neodarwiniści ekstrapolują mechanizmy ewolucyjne na całą rzeczywistość oraz na ich gruncie konstytuują teorię powstania świata i człowieka, co jest błędem, gdyż „tego typu twierdzenia przekraczają kompetencje metod ewolucji biologicznej i genetyki" ${ }^{33}$. W dyskusji nad pochodzeniem gatunków - podkreśla Maryniarczyk - przyrodnicy i filozofowie przyrody bezpodstawnie uzurpują sobie głos rozstrzygający, niepotrzebnie komplikując tę problematykę poprzez formułowanie tzw. naukowej teorii ewolucji, którą należy nazwać mitem, bo jest mieszanką błędnej filozofii i fragmentarycznej wiedzy o mechanizmach zmian organizmów. Zdaniem Maryniarczyka, zwolennicy teorii ewolucji często nie zdają sobie sprawy $\mathrm{z}$ tego, że z obszaru biologicznej teorii ewolucji przechodzą do filogenezy, której analiza należy do metafizyków ${ }^{34}$.

Broniąc tezy o nadprzyrodzonym charakterze genezy poszczególnych gatunków i życia jako takiego, Chaberek utrzymuje, że istnieje zasadnicza różnica pomiędzy interpretacją zjawisk w przyrodzie nieożywionej i ożywionej, dlatego też tak ważna jest wyraźna dystynkcja pomiędzy teorią Kopernika a teorią Darwina. Ta pierwsza - twierdzi Chaberek - odpowiada na pytanie: „Jak świat jest zbudowany?”. Druga z wymienionych teorii rości sobie pretensje do odpowiedzi na pytanie: „Skąd się wzięło życie w takich formach, jakie znamy?", co — jak czytamy - leży poza kompetencjami nauk przyrodniczych ${ }^{35}$. O ile Darwin poprawnie wyjaśnił jak działa mecha-

2005); Pier Luigi LuIsI, The Emergence of Life. From Chemical Origins to Synthetic Biology (Cambridge: CUP, 2006); Horst Rauchfuss, Chemical Evolution and the Origin of Life (Berlin: Springer, 2008); Lluis Ribas de Pouplana, red., The Genetic Code and the Origin of Life (New York: Academic/Plenum, 2004); Joseph SесквACH, red., Origins. Genesis, Evolution and Diversity of Life (New York: Kluwer Academic Publishers, 2004); Pekka TEERIKorPI I IN., The Evolving Universe and the Origin of Life. The Search for Our Cosmic Roots (New York: Springer, 2009); Hubert P. Yockey, Information Theory, Evolution and the Origin of Life (Cambridge: CUP, 2005); Neil H. ShuBIN, „«Wielkie» przejście”, w: Nauka a kreacjonizm. O naukowych uproszczeniach teorii inteligentnego projektu, red. John Brockman, thum. Dariusz Sagan, Sławomir Piechaczek (Warszawa: CIS, 2007), 95-105; Józef ZoN, Zuzanna KieroŃ, „Człowiek jako wytwór ewolucji,” w: Dusza-Umyst-Ciało. Spór o jedność bytowa człowieka, red. Andrzej Maryniarczyk, Katarzyna Stępień (Lublin: Polskie Towarzystwo Tomasza z Akwinu, 2007), 163-178.

\footnotetext{
${ }^{32}$ Maryniarczyk, Dlaczego kreacjonizm?, 69.

${ }^{33}$ MaryniarczyK, Dlaczego stworzenie ,ex nihilo”, 114.

${ }^{34}$ MaryniarczyK, Dlaczego kreacjonizm?, 60.

${ }^{35}$ ChabereK, Stworzenie czy ewolucja, 56-57.
} 
nizm naturalnej selekcji w obrębie danego gatunku, o tyle „bezprawnie” zajmował się kwestią pochodzenia gatunków oraz biogenezą. Chaberek dodaje, że do takiego zagarnięcia pola szybko przyzwyczaili się naukowcy, co w żadnej mierze nie potwierdza właściwych im uprawnień, bo „pytanie o początki nie jest pytaniem naukowym"36.

Zazwyczaj w kręgach kreacjonistycznych uwypukla się różnicę pomiędzy mikro i makroewolucją, by z jednej strony dowieść słabości ewolucjonizmu, z drugiej zaś podkreślić otwartość na nauki przyrodnicze. Mikroewolucja przedstawiana jest jako niekwestionowalny fakt, możliwy do szczegółowego ukazania dzięki darwinowskim badaniom nad mechanizmami ewolucyjnych zmian, na przykład prowadzących do uodparniania się zarodźców malarii na leki. Problem - zdaniem niektórych kreacjonistów - powstaje przy próbie odpowiedzi na pytanie o genezę tychże zarodźców, co miałoby stanowić obszar niedostępny dla przyrodników. W takim kontekście wszelkie próby badania pochodzenia gatunków na płaszczyźnie biologii, przez odwołanie do działania mechanizmów generujących zmiany w obrębie danego gatunku (np. adaptacji), to nieuprawnione przejście od pytania ,jak?” do pytania „skąd?”. Nie ma znaczenia uwzględnienie perspektywy czasowej, bo „czas nie stanowi tu przyczyny”. Według Chaberka, teoria Darwina ma zatem charakter redukcjonistyczny, gdyż rościła sobie prawo do odpowiedzi na pytanie o początki różnorodności rzeczy, które należy do obszaru religiii ${ }^{37}$.

Zdaniem Chaberka przyrodnicy nie są wstanie wyjaśnić zagadki pochodzenia gatunków, bo leży to w kompetencji teologów. Jeżeli ci ostatni pozostawiają analizę problematyki filogenezy przyrodnikom, pośrednio stwierdzają, że makroewolucja biologiczna jest tak samo wartościową teorią przyrodniczą jak np. ogólna teoria względności. Poza tym miałoby to oznaczać aprioryczne uznanie stanowiska naturalistycznego, które wyklucza możliwość nadprzyrodzonego działania Boga. Podstawą dla takich ujęć jest zdaniem Chaberka-przyjęcie „ślepej wiary w ewolucję ${ }^{38}$. Tymczasem nauka „jak dotąd nie zaoferowała żadnych wiarygodnych wyjaśnień ani powstania świata, ani pierwszego życia, ani poszczególnych gatunków [...]. Do natury nauki należy badanie tego jak świat działa, ale nie to, by mówić skąd się wziął. Pochodzenie gatunków stoi dokładnie w centrum tej debaty"39.

\footnotetext{
${ }^{36}$ Tamże, 47.

${ }^{37}$ Tamże, 58-59

${ }^{38}$ Tamże, 100.

${ }^{39}$ Michał CHABereK, Kościół a ewolucja (Warszawa: Fronda, 2012), 343.
} 
Powyższe stwierdzenia nie znajdują uzasadnienia w świetle aktualnych wyników badań przyrodniczych, zawartych między innymi w publikacjach wymienionych wcześniej. Takie zagadnienia jak filogeneza, biogeneza czy kosmogeneza są od lat przedmiotem analiz przyrodników, którzy na podstawie prowadzonych obserwacji formułują teorie naukowe, konfrontując je następnie z kolejnymi danymi empirycznymi. Uwzględnienie doniosłości takich teorii nie oznacza dogmatyzowania nauk przyrodniczych. Granice ich możliwości poznawczych widać zwłaszcza w świetle pytań fundamentalnych, np. „Dlaczego istnieje raczej coś, niż nic?” lub „Jaka jest geneza oraz natura praw przyrody"?

$\mathrm{Z}$ drugiej strony nie ma powodów do tego, by przyrodnicy przestali zajmować się poszukiwaniem przyczyn zjawisk, w którym to kontekście dystynkcja pomiędzy pytaniem ,jak?” i „skąd?” traci na znaczeniu przypisywanym jej przez antyewolucyjnych kreacjonistów. Proponowany przez nich ostry podział na mikro- i makroewolucję także doczekał się relatywizacji i wielu przyrodników podkreśla dziś, że nie są to dwa, lecz jeden proces, zachodzący $\mathrm{w}$ różnych skalach czasowych. Procesy mikroewolucyjne mogą prowadzić do zmian w makroskali, w tym do powstania nowych gatunków ${ }^{40}$. Przyrodnicze teorie filogenezy nie eliminują jednak ipso facto możliwości teistycznej interpretacji ewolucyjnego rozwoju. Działanie Boga w świecie nie musi się realizować contra naturam, zatem konstatacje przyrodników o ciągłym a zarazem emergentnym charakterze rozwoju przyrody można uzgodnić z filozoficzno-teologicznymi ujęciami, uwypuklającymi istnienie nieciągłości ontologicznych na niektórych etapach ewolucji ${ }^{41}$. Podkreślał to wyraźnie Jan Paweł II w przesłaniu do Papieskiej Akademii Nauk z 1996 r. ${ }^{42}$

\section{ROZUMIENIE BIBLIJNYCH OPISÓW STWORZENIA}

Wielu antyewolucyjnych kreacjonistów traktuje biblijne opisy stworzenia jak lekcję historii naturalnej, wykorzystując Pismo św. do obrony stawia-

\footnotetext{
${ }^{40}$ Por. Stephen J. Gould, The Structure of Evolutionary Theory (Cambridge, MA: The Belknap Press of Harvard University Press, 2002), 15; Jeffrey H. Schwartz, Sudden Origins. Fossils, Genes, and the Emergence of Species (New York: Wiley, 1999), 38, Paul R. EhrLich, Human Natures (Washington, DC: Shearwater Books, 2000), 46.

${ }^{41}$ Por. Marek SŁomka, Działanie Boga w świecie. Analiza filozoficzna (Lublin: Wydawnictwo KUL, 2018), 136, 207, 292

${ }^{42}$ Jan Pawel II, „Magisterium Kościoła wobec ewolucji (Przesłanie do członków Papieskiej Akademii Nauk, Watykan 22.X.1996)”, Osservatore Romano 18, nr 1 (1997): 18-19.
} 
nych tez i przeciwstawiając objawienie judeochrześcijańskie naukom przyrodniczym. Nie dostrzegając empirycznych świadectw potwierdzających prawdziwość teorii ewolucji, M. Giertych stwierdza: „Faktem jest stworzenie ex nihilo, faktem, bo mamy na to gwarancję ze źródła nadprzyrodzonego. Walka z Bogiem, z religią, z prawdą objawioną, wymaga znalezienia naturalnego wyjaśnienia powstania świata żywego. Stąd też stawia się nauce wymóg, by takich wyjaśnień szukała. A więc szuka. Wszystko co wskazuje na powstanie świata, przyrody, człowieka w sposób zgodny z opisem w Księdze Rodzaju, jest odrzucane jako nienaukowy fundamentalizm religijny" ${ }^{\prime 3}$.

Powyższe słowa sugerują, że rozwój nauk przyrodniczych służy dyskredytowaniu religii, zaś pierwsza księga Pisma św. zawiera przekaz historii, relacjonujący kolejne etapy rozwoju świata i człowieka. Podobnie konstatują Pajewski ${ }^{44}$ i Chaberek. Zdaniem drugiego, gdyby nie świadectwa biblijne, ludzie mogliby myśleć, że cała różnorodność stworzeń powstała na drodze emanacji jednych bytów z innych. „Tak myśleli poganie ery przedchrześcijańskiej i tak formułuje to współczesna kosmogonia ewolucyjna, na której opiera się cywilizacja postchrześcijańska"45, stwierdza, dodając, że dzięki Księdze Rodzaju poznajemy fałsz takiego myślenia, bo podstawowe elementy świata bezpośrednim działaniem ukształtował Bóg. Chaberek zastrzega, że słowo „dzień” w opisach stworzenia nie oznacza doby, ale podkreśla wagę jego historycznego tłumaczenia, np. w kategoriach jakiegoś odcinka czasu. W takiej interpretacji „Biblia zgadza się z danymi przyrodniczymi, choć nie zgadza się z teorią Darwina" ${ }^{46}$.

$\mathrm{Z}$ jednej zatem strony Chaberek deklaratywnie dystansuje się wobec takiego rozumienia opisów stworzenia, według którego należy je tłumaczyć „słowo po słowie”. Z drugiej strony, wyróżnia on te fragmenty pierwszych rozdziałów Księgi Rodzaju, które powinno się interpretować literalistycznie $^{47}$, np. przekazy o Adamie i Ewie. Zdaniem Chaberka, współczesna her-

${ }^{43}$ Giertych, Nauka na stużbie ideologii, 8-9.

${ }^{44}$ PAJEWSKI, Meandry sporów o pochodzenie, 8.

${ }^{45}$ Chaberek, Stworzenie czy ewolucja, 49.

46 Tamże, 50 .

${ }^{47}$ Używam terminu „literalistyczny” w odróżnieniu od słowa „literalny”. Taka dystynkcja występuje w oficjalnym przekładzie na język polski doniosłego tekstu Papieskiej Komisji Biblijnej: Interpretacja Pisma Świętego w Kościele (Przemówienie Ojca Świętego Jana Pawła II oraz Dokument Papieskiej Komisji Biblijnej), tłum. K. Romaniuk (Poznań: Pallottinum, 1994). Czytamy tam, że przy próbie zrozumienia Pisma św. „koniecznie powinno się podejmować wszelkie wysiłki, aby określić dokładnie sens tekstu w takiej jego postaci, jak był zredagowany przez jego autora. Taki sens nazywa się dosłownym. [...] Sensu dosłownego, czyli literalnego nie należy 
meneutyka biblijna, która odeszła od historycznego tłumaczenia tekstów dotyczących pierwszych rodziców, prowadzi do pozbawienia Pisma św. wszelkiego znaczenia ${ }^{48}$.

Brak jednoznacznego, a czasem nawet jakiegokolwiek odniesienia do aktualnej wiedzy z zakresu krytycznej egzegezy biblijnych opisów stworzenia jest błędem powielanym w wielu publikacjach katolickich. Przybliżają one losy pierwszych rodziców na takim samym poziomie interpretacyjnym, jak historie świętych i błogosławionych Kościoła. W jednym z najpopularniejszych religijnych portali internetowych w Polsce, www.brewiarz.pl, przy wspomnieniu Adama i Ewy jako patronów na 24 grudnia czytamy, że nie ma „ani jednego wśród pisarzy kościelnych, który by miał odwagę umieszczać rodziców rodzaju ludzkiego wśród potępionych” oraz: „Powszechne jest przekonanie, że Adam i Ewa pokutą zadośćuczynili Bogu w tej mierze, w jakiej byli zdolni to uczynić" 49 . W podległym Konferencji Episkopatu Polski serwisie Katolickiej Agencji Informacyjnej redaktorzy Internetowego Dziennika Katolickiego przedstawiają pierwszych rodziców w taki sposób, $\mathrm{w}$ jaki w innych dniach prezentowany jest św. Franciszek z Asyżu czy św. Jan Paweł $\mathrm{II}^{50}$. Ani pierwszy ani drugi z wymienionych tekstów nie zawiera komentarza hermeneutycznego.

mieszać z sensem literalistycznym, za istnieniem którego opowiadają się fundamentaliści. Do odnalezienia sensu dosłownego nie wystarczy przetłumaczyć tekst słowo po słowie" (s. 67).

${ }^{48}$ ChabereK, Stworzenie czy ewolucja, 52-54, 90-92. Wybiórcze traktowanie jednych fragmentów pierwszych rozdziałów Księgi Rodzaju jako opisu historii, innych zaś w kategoriach symboliczno-metaforycznych krytycznie ocenia Michał Heller w książce Nauka i Teologia niekoniecznie tylko na jednej planecie (Kraków: Copernicus Center Press, 2019), rozdz. 6.1.

${ }^{49}$ https://brewiarz.pl/czytelnia/swieci/12-24.php3 (dostęp 20.08.2020).

${ }^{50}$ Chodzi tu o Internetowy Dziennik Katolicki z 23 grudnia 2019 r., rozsyłany przez KAI droga elektroniczną. Od co najmniej kilku lat KAI przesyła do subskrybentów w dniu 23 grudnia taki sam tekst o pierwszych rodzicach. Zawarty tam w wykazie świętych i błogosławionych na następny dzień opis nie zawiera jakiejkolwiek informacji o tym, że pierwsze rozdziały Księgi Rodzaju nie są przekazem historii naturalnej. Po takiej lekturze, odbiorcy mogą się zatem na przykład zastanawiać, jakie są (choćby w przybliżeniu) daty śmierci Adama i Ewy, zwłaszcza, że w notce pojawia się zdanie: „Adam miał żyć 930 lat”. Do takiego sformułowania koniecznie należałoby dodać stosowny komentarz, np. fragment książki autorstwa D. Dziadosza pt. Tak było na początku. Izrael opowiada swoje dzieje (Przemyśl: Wydawnictwo Archidiecezji Przemyskiej, 2011), w której — po wnikliwej analizie hermeneutycznej — czytamy, że długowieczność postaci z pierwszych rozdziałów Księgi Rodzaju ma „wymiar jedynie symboliczny a nie rzeczywisty, i w swej istocie służy przede wszystkim względom teologicznym i literackim, jakimi kierował się edytor tych tradycji biblijnych" (s. 209). Trzeba w tym miejscu dla sprawiedliwości wspomnieć, że na stronie internetowej Katolickiej Agencji Informacyjnej (https://ekai.pl/wigiliebozego-narodzenia-wspomnimy-adama-i-ewe) tekst dotyczący pierwszych rodziców jest znacz- 
W powyższym kontekście należy podkreślić, że wiele powszechnie dostępnych publikacji zawiera wnikliwą analizę specyfiki przekazu pierwszych rozdziałów Księgi Rodzaju ${ }^{51}$. Znaczenie rozwiniętej w minionych dziesięcioleciach hermeneutyki biblijnej wyraźnie uwypuklają także dokumenty Kościoła katolickiego, ukazując ją jako racjonalną reakcję na „wszelkie próby zastosowania w studiach nad Biblią kryteriów obiektywizmu, postulowanego przez nauki przyrodnicze ${ }^{\text {,52 }}$. Papieska Komisja Biblijna stwierdza: „Przy interpretacji Biblii nie można obyć się bez skorzystania z teorii hermeneutycznej, która pozwala wprowadzić metodę krytyki literacko-historycznej do bardziej pojemnego modelu interpretacyjnego. Chodzi o swoiste pokonanie dystansu, dzielącego czasy autorów i pierwszych adresatów tekstów biblijnych od epoki nam współczesnej, aby w ten sposób doprowadzić do poprawnego zaktualizowania przesłania tych tekstów [...]. Każda egzegeza tekstów powinna być uzupełniana «hermeneutyką», we współczesnym rozumieniu tego terminu",53.

Jednocześnie autorzy watykańskiego dokumentu przestrzegają przed fundamentalistyczną lekturą Pisma św., która absolutyzuje „bezbłędność różnych szczegółów tekstów biblijnych zwłaszcza historycznych i nawiązujących do rzekomych prawd naukowych. Często historycyzuje nawet to, co ze swej natury nie może uchodzić za historyczne. Uważa bowiem za historyczne to wszystko, co zostało przekazane przy użyciu słów w czasie przeszłym, nie zwracając uwagi na możliwość zaistnienia sensu symbolicznego lub metaforycznego" ${ }^{54}$. Te jednoznaczne słowa odniesione są do konkretnych przejawów nastawienia fundamentalistycznego, które odznacza się skłonnością do „zawężania perspektyw badawczych przez to, że uważa za zgodną z rzeczywistością pewna starożytną kosmologię, a przecież już nieaktualną kosmologię dlatego tylko, że jej ślady znajduje w Biblii. Utrudnia to ogromnie wszelki dialog z szerszym sposobem pojmowania relacji, jakie zachodzą pomiędzy kulturą a wiarą" ${ }^{55}$. Konkluzją radykalnie negatywnej oceny biblij-

nie lepszy, choć nie pozbawiony wad, o których piszę w niniejszym artykule przy analizie kwestii $\mathrm{z}$ zakresu filozofii nauki.

${ }^{51} \mathrm{~Np}$. Andrzej Piwowar, „Biblijny opis stworzenia świata i człowieka w odniesieniu do nauk przyrodniczych", w: Naukowy a religijny obraz początku wszechświata i człowieka. Perspektywy dialogu, red. Jacek Golbiak, Karol Jasiński, Wojciech Kotowicz (Olsztyn: Wydział Teologii UWM, 2015), 49-95; Peter van Inwagen, Księga Rodzaju a ewolucja, tłum. Marcin Iwanicki, Marek Osmański, Roczniki Filozoficzne 52, nr 1 (2004): 363-398.

${ }^{52}$ Papieska Komisja Biblijna, Interpretacja Pisma Świętego w Kościele, tłum. Kazimierz Romaniuk (Poznań: Pallottinum, 1994), 65.

${ }^{53}$ Tamże, 64.

54 Tamże, 59.

55 Tamże, 60. 
nego fundamentalizmu jest stwierdzenie, że popycha on ludzi „w kierunku swoistego samobójstwa myślowego" ${ }^{, 56}$.

\section{INTENSYFIKACJA DZIAŁAŃ \\ ANTYEWOLUCYJNYCH KREACJONISTÓW}

Okresem szczególnej intensyfikacji działań antyewolucyjnych kreacjonistów w Polsce była druga połowa 2006 r. Dogodnym gruntem do takiego rozwoju sytuacji stały się przemiany polityczne, w konsekwencji których wiele osób publicznie podkreślających swoje przywiązanie do tradycji chrześcijańskiej miało duży wpływ na opinię społeczną. Była ona kształtowana także przez liczne mass media, zaangażowane zarówno w popularyzację nauki, jak i w przekaz religijny ${ }^{57}$.

W październiku 2006 r. Maciej Giertych twierdził: „Badania pokazują, że dinozaury były współczesne ludziom. Ze wszystkich kultur docierają informacje, że je pamiętamy. Szkoci - potwora z Loch Ness, my - smoka wawelskiego, a Marco Polo pisał, że smok był zaprzężony do karety cesarskiej

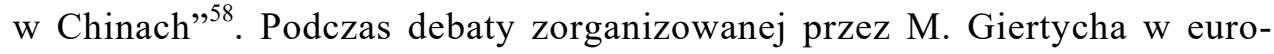
parlamencie podawano argumenty na rzecz zniesienia obowiązkowej edukacji w szkołach w zakresie teorii ewolucji. Apelowano zwłaszcza, by krytycznie podchodzić do ewolucyjnych teorii pochodzenia człowieka. Przekonywano, że należy nauczać teorii kreacjonistycznej, która zakłada, że wszechświat, człowieka i wszystkie inne organizmy w niewielkich odstępach czasowych stworzył Bóg. Zdaniem Giertycha, teoria ewolucji nie znajduje potwierdzenia w danych empirycznych, w szkołach zaś ,powinno się uczyć tego, co znajduje poparcie w obserwacji, a nie teorii" ${ }^{, 59}$.

\footnotetext{
${ }^{56}$ Tamże, 61 .

${ }^{57} \mathrm{Na}$ przykład Fronda, Christianitas, Niedziela, Radio Maryja, TV Trwam, Idź pod prąd, Opoka w Kraju, Polonia Christiana, www.kreacjonizm.org.pl.

${ }^{58}$ Maciej Giertych, „Dinozaury żyły w czasach ludzi”, Wprost, 23.10.2006, dostęp 18.08. 2020, https:/www.wprost.pl/96230/maciej-giertych-dinozaury-zyly-w-czasach-ludzi.html; archiwum czasopisma Opoka w Kraju, http://opoka.giertych.pl/evolution.pdf, 10. Por. też MARYNIARCZYK, Dlaczego kreacjonizm?, 50.

${ }^{59}$ Marcin SzYMAnIAK, „Maciej Giertych chce wyrzucić ewolucję ze szkół”, Życie Warszawy, 12.10.2006, dostęp 17.08.2020, http://www.zw.com.pl/artykul/192900.html; Maciej GIERTYCH, „Creationism, Evolution. Nothing Has Been Proved”, Nature, nr 444 (2006): 265, https:// www. nature.com/articles/444265d; „Kto podważa teorię Darwina”, Nauka w Polsce, 17.10.2006, dostęp 20.08.2020, https://naukawpolsce.pap.pl/aktualnosci/news\%2C25674\%2Ckto-podwazateorie-darwina.html.
} 
Roman Giertych (syn prof. Macieja Giertycha), który w latach 2006-2007 był ministrem edukacji, podkreślał: „Teoria ewolucji to tylko koncepcja, a nie fakt naukowy. Na obecność w programach różnych teorii naukowych rodzice powinni mieć wpływ. Trudno mi teraz przesądzić, czy powinni mieć prawo wyboru podręcznika $-\mathrm{z}$ teorią ewolucji albo bez. O tym trzeba w Polsce rozpocząć dopiero dużą dyskusję"60. 12 października 2006 r. W wywiadzie radiowym uznał, że „teoria ewolucji jest jedną z wielu teorii o powstaniu życia na Ziemi i jest sprawą nauczycieli i rodziców, czy znajdzie się w programach nauczania" ${ }^{61}$.

Ówczesny wiceminister edukacji, Mirosław Orzechowski, twierdził: „teoria ewolucji to kłamstwo. Mam przekonanie, że to pomyłka, którą zalegalizowano jako obowiązującą prawdę. Dla mnie to opowieść o charakterze literackim, mogłaby np. stać się kanwą filmu science fiction. Sama teoria Darwina jeszcze za jego życia była modyfikowana, podawano kolejne fakty, które ją kwestionowały. To w zasadzie luźna koncepcja niewierzącego starszego pana, który tak właśnie widział świat [...]. To smutne, a tego uczy się w polskiej szkole" ${ }^{22}$. Zastrzegając, że teoria ewolucji nie będzie usuwana z podręczników szkolnych, Orzechowski dodawał: „Darwinizm był tylko motywacją intelektualną dla ludzi niewierzących, stał się paranaukową argumentacją dla nich. Tymczasem w chrześcijaństwie przetrwała 2000 lat inna koncepcja: kreacjonizm. To cywilizacyjna prawda, która płynie z wiary, jest powtarzana i niezakwestionowana od tysięcy pokoleń" ${ }^{\prime 63}$.

Podważanie naukowego charakteru teorii ewolucji przez osoby odpowiedzialne za edukację w polskich szkołach sprzyjało pojawianiu się wielu publikacji o podobnych treściach. Publicystom z kręgów kościelnych mogło się wydawać, że poddając krytyce dorobek nauki robią przysługę religii chrześcijańskiej. W listopadzie 2006 r. Ewa Polak-Pałkiewicz pisała na łamach tygodnika katolickiego Niedziela: „Ewolucjoniści cienko przędą, jeśli idzie o dowody naukowe [...] przyjęcie teorii ewolucji jest nadal kwestią wiary [...]. Według prawa selekcji — naczelnej zasady tej teorii — ze śmierci, $\mathrm{z}$ obumierania ma powstawać kolejna, doskonalsza forma życia. A więc z ro-

\footnotetext{
${ }^{60}$ Konrad NiKLEwicz, “Giertych chce zakazać Darwina w szkołach”, Gazeta.pl, 13.10.2006, dostęp 20.08.2020, https://wiadomosci.gazeta.pl/wiadomosci/1,114873,3682091.html.

${ }^{61}$ Cyt. za: „UW: teoria ewolucji jest powszechnie uznawana”, Wirtualna Polska, 19.10.2006, dostęp 20.08.2020, https://wiadomosci.wp.pl/uw-teoria-ewolucji-jest-powszechnie-uznawana$6037394343776897 \mathrm{a}$.

${ }_{62}$ Aleksandra PEZDA, „Wiceminister edukacji: Poradzimy sobie bez tolerancji”, Gazeta.pl, 14.10.2006, dostęp 21.08.2020, https://wiadomosci.gazeta.pl/wiadomosci/ 1,114873, 3684136.html.

${ }^{63}$ Tamże.
} 
śliny zwierzę, ze zwierzęcia człowiek. Ta absurdalna teza otwiera drogę najstraszniejszym ideologiom, których ludzkość doświadczyła w XIX i XX wieku" ${ }^{\prime 4}$. Całość tekstu opatrzona jest znamiennym tytułem Ewolucja-obtok wiedzy czy ideologii.

\section{REAKCJA ŚRODOWISK NAUKOWYCH}

$\mathrm{Na}$ intensyfikację działań oraz tezy stawiane przez antyewolucyjnych kreacjonistów zareagowało Prezydium Komitetu Biologii Ewolucyjnej i Teoretycznej Polskiej Akademii Nauk. Jego członkowie wydali oświadczenie, ostrzegające przed zagrożeniem drastycznego obniżenia poziomu nauczania biologii i nauk o Ziemi w szkołach średnich. Zwrócono uwagę na to, że teoria ewolucji należy do zbioru teorii z dziedziny nauk empirycznych (takich jak teoria grawitacji czy teoria heliocentryczna Kopernika), które tym różnią się od innych gałęzi wiedzy, że z ich stwierdzeń lub teorii można wyprowadzić wnioski dające się sprawdzić, a teorię obalić przez eksperyment lub obserwację. W tym kontekście podkreślono, że od czasów prezentacji teorii ewolucji uczeni stale ją testują oraz wyprowadzają z niej wnioski i jak dotychczas nie udało się jej obalic ${ }^{65}$.

Do skrajnych ujęć kreacjonistycznych odniósł się krytycznie także Senat Uniwersytetu Warszawskiego, przyjmując jednomyślnie jako swoje oficjalne stanowisko uchwałę Rady Wydziału Biologii UW z 16 października 2006 r. w sprawie nauczania teorii ewolucji. Podkreślono w niej, że darwinowska teoria ewolucji jest powszechnie uznawana w świecie naukowym, zaś kreacjonizm nie jest teorią naukową. Według senatu UW, wypowiedzi ministra i wiceministra edukacji na temat ewolucji dowodzą, że „są oni skrajnie niekompetentni”,66.

Swoje stanowisko $\mathrm{w}$ publicznym sporze wyraziła również konferencja dziekanów wydziałów przyrodniczych polskich uczelni. W liście otwartym skierowanym do najwyższych władz państwowych RP krytycznie odniesiono się zarówno do stanowiska M. Giertycha w sprawie nauczania teorii ewolucji, jak i do wypowiedzi ministra oraz wiceministra edukacji, dotyczących

\footnotetext{
${ }^{64}$ E. Polak-PaŁkiewicz, „Ewolucja - obłok wiedzy czy ideologii”, Niedziela, nr 46 (2006): 26, dostęp 17.08.2020, https://www.niedziela.pl/artykul/80613/nd/Ewolucja---oblok-wiedzy-czyideologii.

${ }^{65}$ „Wiedza kontra ignorancja”, Sprawy Nauki, 9.11.2006, dostęp 2.09.2020, http://www. sprawynauki.edu.pl/archiwum/dzialy-wyd-papierowe/197-naukowa-agora/212-149.

66 „Wykładowcy o teorii ewolucji”, Nauka w Polsce, 20.10.2006, dostęp 2.09.2020, https:// naukawpolsce.pap.pl/aktualnosci/news\%2C25769\%2Cwykladowcy-o-teorii-ewolucji.html.
} 
tego, że teoria ewolucji jest jedną z wielu teorii powstania życia na Ziemi, więc jest sprawą nauczycieli oraz rodziców, czy znajdzie się w programach nauczania szkolnego. Akcentowano, że przeciwstawianie teorii ewolucji kreacjonizmowi i równoległe omawianie tych dwóch podejść na lekcjach biologii nie ma sensu, gdyż kreacjonizm nie jest teorią naukową. „Dziś” — napisano w liście - ,prawie 150 lat po ogłoszeniu dzieła Darwina, nie tylko żaden rozsądny naukowiec, lecz także żaden człowiek mający choćby najbardziej podstawową wiedzę przyrodniczą, nie neguje istnienia ewolucji. Nikt już obecnie faktu ewolucji nie stara się udowadniać" ${ }^{67}$.

20 października 2006 r. swoje oświadczenie wydali katoliccy wykładowcy filozofii przyrody, powołując się na przesłanie Jana Pawła II skierowane do Papieskiej Akademii Nauk 22 października 1996 r., w którym papież pokazuje możliwości uzgodnienia ewolucyjnej teorii powstania człowieka $\mathrm{z}$ chrześcijańską koncepcją stworzenia. Autorzy oświadczenia napisali, że w pewnych środowiskach usiłuje się „bezpodstawnie kwestionować papieską wizję współpracy nauki i wiary, wprowadzając na jej miejsce obce katolicyzmowi opracowania inspirowane przez zasady antynaukowego fundamentalizmu"68. Pod dokumentem podpisali m.in. Wiesław Dyk, Zygmunt Hajduk, Michał Heller, Janusz Mączka, Józef Turek, Stanisław Wszołek i Józef Życiński.

\section{EDUKACJA RELIGIJNO-KATECHETYCZNA}

Jednoznaczna reakcja środowisk naukowych mogła być jednym z powodów, który zahamował proces zmian w programach nauczania przedmiotów przyrodniczych w polskich szkołach. Przekaz antyewolucyjnych kreacjonistów znalazł jednak w kolejnych latach podatny grunt w niektórych podręcznikach do nauki religii. Było to tym łatwiejsze, że w marcu 2010 r. — niezależnie od przedstawionego wyżej przebiegu zdarzeń - uległy modyfikacji podstawy programowe katechezy Kościoła katolickiego w Polsce, więc trzeba było zredagować nowe podręczniki dla uczniów oraz poradniki katechetyczne dla przygotowujących poszczególne lekcje nauczycieli. W kolej-

67 „Dziekani: ewolucja istnieje, a Giertych i Orzechowski kompromitują kraj”, Wirtualna Polska, 25.10.2006, dostęp 29.08.2020, https://wiadomosci.wp.pl/dziekani-ewolucja-istnieje-a-giertych-i-orzechowski-kompromituja-kraj-6037394693579393a.

${ }^{68}$ „Katoliccy filozofowie: nie ma konfliktu między ewolucją a stworzeniem”, $e K A I, 20.10$. 2006, dostęp 2.09.2020, https://ekai.pl/katoliccy-filozofowie-nie-ma-konfliktu-miedzy-ewolucjaa-stworzeniem. 
nych kilku latach publikowały je uprawnione do tego wydawnictwa: Gaudium, Jedność, WAM, Święty Wojciech, Wydawnictwo Katechetyczne, Wydawnictwo św. Stanisława BM oraz Wydawnictwo Diecezjalne w Sandomierzu. Mimo że w 2017 r. polski system edukacji przeszedł gruntowną reformę, wydane w latach 2011-2016 książki do katechezy do dziś pozostały w wielu szkołach podstawowym źródłem przekazu treści religijnych. Poniżej przedstawię główne problemy pojawiające się w tych publikacjach przy prezentowaniu ewolucjonizmu i kreacjonizmu oraz zachodzącej między nimi relacji. Zasadnicze błędy wskażę także na podstawie tekstów dotyczących genezy wszechświata i jego ewolucji, które to zagadnienia wprowadzane są często łącznie z biologiczną teorią ewolucji i w podobnie nieudolny sposób. Wyróżnię przede wszystkim elementy ujawniające wpływ zaprezentowanych wyżej tez kreacjonistycznych na treści zawarte w jednostkach lekcyjnych. Fragmenty, na które należy zwrócić szczególną uwagę, zaznaczę kursywą.

W jednostce lekcyjnej „Prawda o początku” zawartej w podręczniku wydanym przez WAM można $\mathrm{z}$ jednej strony dostrzec zaangażowanie autorów mające na celu ukazanie komplementarności religii i nauki w zakresie poszukiwania prawdy o genezie świata i człowieka. $Z$ drugiej strony, opis zawiera liczne uproszczenia a także merytoryczne błędy. Czytamy, że współcześni przyrodnicy

starają się wykazać, że kilkanaście miliardów lat temu cały wszechświat skupiony był w jednym punkcie o nieskończonej gęstości i temperaturze. $W$ pewnym momencie - około 13 miliardów lat temu - punkt ten zaczął się gwałtownie rozszerzać. Moment ten nazywany jest Wielkim Wybuchem (z angielskiego: Big Bang). Inna teoria, zwana ewolucjonizmem, zrodziła się na gruncie rozważań biologicznych w XIX wieku [...]. Zgodnie z nią wszystkie istoty żywe łącznie z człowiekiem powstały w wyniku przypadkowych zdarzeń trwających miliardy lat. Dzięki nim $z$ chaosu wytoniła się doskonała konstrukcja i porzadek wszechświata. (Podkr. M. S.) ${ }^{69}$

Widać, że autorzy tekstu nie rozumieją teorii wielkiego wybuchu, zwłaszcza gdy chodzi o kontekst czasowy (,w pewnym momencie”). Z elementami nauki pomieszane są naiwne wyobrażenia o przejściu świata $\mathrm{z}$ bezładu do stanu absolutnego uporządkowania. Ewolucjonizm rozpatrywany na gruncie biologicznym opisany jest wyłącznie w kategoriach losowości procesów, co bez odpowiedniego komentarza wyraźnie kontrastuje z chrześcijańską doktryną dotyczącą opatrzności Boga oraz zaplanowania przez niego (nomen omen) losów stworzenia, zwłaszcza genezy człowieka.

\footnotetext{
${ }^{69}$ Jezus uczy i zbawia (Podręcznik do nauki religii dla I klasy gimnazjum), red. Zbigniew Marek $\mathrm{i}$ in. (Kraków: WAM, 2012), 36.
} 
Jednostka katechetyczna „Jak powstał świat?”, zamieszczona w podręczniku z Wydawnictwa św. Wojciecha, odnosi się zarówno do teorii naukowych, jak i religijnych. Warto przytoczyć dłuższy passus tekstu, który bazując na fragmencie książki André Frossarda — w treści i formie ma wiele usterek:

Jak tego dowodzi odległość od czerwieni widma galaktyk, świat jest w stanie rozszerzania się, trochę jak wiązka sztucznego ognia. Aby galaktyki byty w stanie ucieczki, trzeba, by mialy jakiś punkt wyjścia. Przypuszcza się więc, że na początku cała masa wszechświata była skondensowana w jednym niedostrzegalnym punkcie, o wiele mniejszym od główki szpilki, i że w tym punkcie panowała przerażająco wysoka temperatura. W pewnym momencie, dziesięć lub piętnaście miliardów lat temu, dokonało się coś, co było nie tyle wybuchem w ścisłym znaczeniu, ile raczej gwałtownym rozszerzaniem się owej masy, któremu towarzyszyło wyzwolenie się ogromnej energii w próżni. Owa energia zamieniła się w materię w czasie rozszerzania się początkowego punktu fizycznego, aż do ukształtowania poprzez serię metamorfoz (wyraz jest niewtaściwy, lecz każdy inny byłby również taki) wszechświata, który trwa w ciaglej ekspansji o rozmiarach wykraczajacych poza zasięg naszych teleskopów. (Podkr. M. S.) ${ }^{70}$

Wiedza autora katechezy na tematy kosmologiczne, przekazywana w zagmatwany sposób, pochodzi sprzed ponad pół wieku. Czytamy, że teoria wielkiego wybuchu, „ostatnio sprecyzowana przez fizyka Gamowa”, przyjmowana jest przez większość astrofizyków i nie sprzeciwia się judeochrześcijańskiej nauce o stworzeniu, bo określa jakiś początek wszechświata. Jednocześnie pada zastrzeżenie, że teoria wielkiego wybuchu zawiera sporo niejasności: „Kiedy mówi się, że gwałtowne rozszerzenie się pierwotnego punktu fizycznego wyzwala ogromną ilość energii w próżni, jest rzecza oczywista, iż owo przejście od punktu fizycznego (od ,główki szpilki”, w której skupia się masa wszechświata) do próżni, próżni absolutnej i pierwotnej-stanowi problem równie trudny do określenia, jak każda z tajemnic chrześcijańskich" 71 (podkr. M. S.). Podkreślone przeze mnie fragmenty świadczą o braku elementarnej wiedzy naukowo-filozoficznej autorów tekstu. Poszczególne zdania są fatalnie skonstruowane i mają szereg błędów przedmiotowych i językowych, zaś używane porównania nie pomogą uczniom w uchwyceniu istoty rzeczy. Kompromitującym — w świetle tempa rozwoju kosmologii - jest stwierdzenie, że teoria wielkiego wybuchu została ostat-

\footnotetext{
${ }^{70}$ Moje miejsce $w$ świecie (Podręcznik do nauki religii dla II klasy szkół ponadgimnazjalnych), red. Jan Szpet, Danuta Jackowiak (Poznań: Wydawnictwo św. Wojciecha, 2013), 19.

${ }^{71}$ Tamże.
} 
nio sprecyzowana przez Gamowa (zmarł w 1968 r.). Przykładem ignorancji pozostaje datowanie wielkiego wybuchu, które bez komentarza wskazuje na alternatywne warianty różniące się o 5 miliardów lat. Widać też niezrozumienie kwestii genezy czasu oraz nieudolną próbę uzgodnienia teorii naukowej z kreacjonizmem. Utożsamianie wielkiego wybuchu z kreacją świata przez Boga jest metodologicznym błędem, przed którym przestrzegał już w połowie XX w. Georges Lemaître ${ }^{72}$. Wielu filozofujących przyrodników podkreśla, że wszechświat czasowo nieskończony może być zarazem stworzony $^{73}$.

W tej samej jednostce lekcyjnej przywołany jest następnie biblijny opis stworzenia świata i człowieka, który — według twórców podręcznika - ma przede wszystkim znaczenie religijne i teologiczne, więc ,wielokierunkowe badania dotyczące powstania i rozwoju poszczególnych gatunków w przyrodzie nie znajdują w tym opisie ani żadnej «wiążącej» dyrektywy [podkr. M. S.], ani też istotnego ograniczenia. Co więcej, z prawdą o stworzeniu świata widzialnego - tak jak jest ona przedstawiona w Księdze Rodzaju — nie koliduje również w zasadzie teoria ewolucji przyrody, jeśli nie wyklucza się w niej przyczynowości Bożej”" ${ }^{\text {,4 }}$. Widać, że autorom zależy na przekazaniu, że można równocześnie przyjmować naukowy i religijny obraz świata. Należałoby jednak pewne treści werbalizować bardziej jednoznacznie, bo biblijne opisy stworzenia nie tyle nie zawierają ,żadnej wiążącej dyrektywy" dla nauki, ile w ogóle nie mogą być traktowane jako ograniczenie dla badań przyrodniczych.

Próba komplementarnego ujęcia religijnego i naukowego aspektu genezy człowieka podjęta została także przez autorów jednostki katechetycznej „Stworzony na obraz i podobieństwo Boże”. We wprowadzeniu czytamy:

Od czasu, kiedy Karol Darwin [...] utorował szeroką drogę dla teorii ewolucji, wielu ludzi stanęło wobec alternatywy: stworzenie czy ewolucja człowieka? Szczególnie ostrej krytyce poddał teksty biblijne opowiadające o stworzeniu człowieka Ernst Haeckel [...]. Fragment Biblii, który mówi o tym, jak to w wyniku ulepienia przez Boga ciała $\mathrm{z}$ mułu ziemi i tchnięcia $\mathrm{w}$ nie duszy powstał człowiek jako żywa istota, napotyka odtąd na jawną nieufność. Czyż liczne znaleziska wczesnoludzkich szczątków nie są oczywistym dowodem świadczącym

\footnotetext{
${ }^{72}$ Por. Tadeusz PABjan, „Czy nauka dowodzi istnienia Boga? Naukowa apologetyka Piusa XII”, Studia Philosophiae Christianae 45, nr 2 (2009): 286-290.

${ }^{73}$ Por. np. Józef TuRek, „Wszechświat czasowo nieskończony i stworzony”, Studia Warmińskie 28 (1991): 217-233.

${ }^{74}$ Moje miejsce w świecie, 20.
} 
przeciwko tezie o stworzeniu gotowego człowieka, a nie na korzyść teorii ewolucji? Kto ma rację: Mojżesz czy Darwin? (Podkr. M. S.) ${ }^{75}$

Takie zestawienie osób w ostatnim zdaniu wydaje się bezsensowne ${ }^{76}$. Należałoby przynajmniej dookreślić rolę Mojżesza w tym kontekście, by czytający uchwycili sugestię autora. Jeśli chodziłoby o autorstwo Księgi Rodzaju to uczniowie są wprowadzani w błąd, bo współcześni egzegeci wyrażają zasadnicze zastrzeżenia co do roli Mojżesza w jej powstaniu ${ }^{77}$.

W następnej części tekstu autorzy utrzymują, że przyrodnicy zajmujący się antropogenezą stawiają bardzo zróżnicowane tezy. „W czasach nowożytnych szczególnym zagadnieniem dla objawionej nauki o stworzeniu człowieka jako istoty złożonej z duszy i ciała stała się teoria ewolucji. Wielu specjalistów w zakresie nauk przyrodniczych, którzy przy pomocy metod sobie właściwych badają sprawę początków człowieka na ziemi, daje wyraz - w przeciwieństwie do wielu innych swoich kolegów - nie tylko przeświadczeniu o jego związku z całokształtem przyrody, ale także o pochodzeniu człowieka od najwyższych gatunków zwierzęcych" (podkr. M. S.) ${ }^{78}$. $\mathrm{Z}$ tekstu nie wynika niestety, że - przy uwzględnieniu wątpliwości badaczy dotyczących pewnych aspektów filogenezy człowieka - bogactwo cytowanej wyżej fachowej literatury na ten temat jednoznacznie manifestuje wiodący nurt wśród przyrodników w tym zakresie.

W trzeciej sekcji, zatytułowanej „U źródeł mądrości”, pojawia się odniesienie do encykliki Piusa XII, który podkreśla, że magisterium Kościoła nie zabrania badań nad teorią ewolucji, mającą za przedmiot pochodzenie ciała ludzkiego ${ }^{79}$. Przywołując papieski tekst, autorzy jednostki katechetycznej piszą, że z punktu widzenia nauki wiary nie widać trudności z przyjęciem hipotezy ewolucyjnego pochodzenia ciała człowieka, ale podkreślają zarazem: „chociaż trzeba dodać, że hipoteza wskazuje tylko na prawdopodobieństwo, a nie mówi o naukowej pewności" ${ }^{80}$. Takie zastrzeżenie wynika z niezna-

\footnotetext{
${ }^{75}$ Tamże, 29.

${ }^{76}$ Można przypuszczać, że mamy tu do czynienia z aluzją do tytułu książki XIX-wiecznego wolnomyśliciela: Arnold Dodel-Port, Moses oder Darwin? Eine Schulfrage. Allen freunden der wahrbeit zum nachdenken vorgelegt (Zurich: C. Schmidt, 1889).

${ }^{77}$ Jean-Louis SKA, Introduction to Reading the Pentateuch, thum. Pascale Dominique (Winona Lake, IN: Eisenbrauns, 2006), 102-107. PAPIESKA Komisja Biblijna, Interpretacja Pisma Świętego w Kościele, 26-27.

${ }^{78}$ Moje miejsce $w$ świecie, 29.

${ }^{79}$ PIUS XII, Encyklika Humani generis (Vaticano: LEV, 1950), cz. 3, 1; tekst polski dostępny na: https://biblia.wiara.pl/doc/423146.encyklika-humani-generis/7 (dostęp 2.09.2020).

${ }^{80}$ Moje miejsce w świecie, 29.
} 
jomości wyników badań z zakresu antropogenezy oraz podstawowych elementów filozofii nauki, o których pisałem w pierwszej części niniejszego artykułu. Podobny sposób myślenia widoczny jest zarówno przy analizie zagadnienia pochodzenia człowieka, jak i genezy świata. Autorzy podręcznika wydanego w Krakowie podkreślają, że współczesna kosmologia nie dysponuje wiedzą całkowicie pewną a posiadana wiedza o świecie, a tym bardziej o jego początkach, jest ,jedynie interpretacją poczynionych obserwacji" ${ }^{\prime 81}$. Kluczem do zaznaczenia niepewności wiedzy przyrodniczej są tu słowa „tylko” i ,jedynie”, wyraźnie modelujące myślenie czytelnika.

Kwestię ewolucjonizmu podejmuje podręcznik do katechezy, który ukazał się nakładem wydawnictwa Gaudium. W jednostce lekcyjnej „Stworzenie świata a ewolucja” czytamy, że przeciw teorii ewolucji świadczą: „brak dowodów istnienia form pośrednich (np. między ptakami a ssakami), niezmienność niektórych gatunków przez miliony lat, druga zasada termodynamiki - (w przyrodzie typowy jest rozpad i dążenie do nieporządku, a nie ewolucja i rozwój), fiasko laboratoryjne wywoływanych mutacji, równoległe istnienie form niższych i wyższych" ${ }^{\text {" }}$. Przynajmniej część tych ,argumentów" spotkała się już dawno $\mathrm{z}$ naukową krytyką ${ }^{83}$, więc nie można zaakceptować cytowanego przekazu, nawet przy uwzględnieniu faktu, że autorzy podają najpierw argumenty „za" teorią ewolucji. Zaproponowany sposób przedstawiania treści nie jest dowodem obiektywnej prezentacji i zaciera granicę między nauką a pseudonauką, gdyż pierwszy zbiór argumentów jest zgodny ze współczesną wiedzą przyrodniczą, drugi zaś nie.

Pomimo deklaracji autorów, że pierwsze rozdziały Księgi Rodzaju nie opisują historii naturalnej, we wprowadzeniu do omawianego tematu znajduje się pytanie „Czy Adam i Ewa mogli przypominać małpy?”, które pomijając niskich lotów zabieg stylistyczny - skłania uczniów do traktowania tego przekazu biblijnego w kategoriach relacji z przebiegu zdarzeń ze świata fizycznego. Poza tym, błędnie przedstawiony jest zarówno ewolucjonizm, jak i kreacjonizm. Autorzy podkreślają, że teoria ewolucji nie jest zagrożeniem dla wiary chrześcijańskiej, ale dodają zarazem: „Jest nim natomiast ideologizacja tej hipotezy naukowej, czyli prezentowanie jej w taki

\footnotetext{
${ }^{81}$ Jezus uczy i zbawia, 37.

${ }^{82}$ Świadcze o Jezusie $w$ świecie (Podręcznik do nauki religii dla II klasy szkół ponadgimnazjalnych), red. Robert Strus, Wiesław Galant (Lublin: Gaudium, 2013), 22.

${ }^{83}$ Marian KowALSKI, „Argumenty kreacjonistów? Obal je wszystkie”, totylkoloteria.pl, 11.03. 2018, dostęp 2.09.2020, https://www.totylkoteoria.pl/2018/03/argumenty-kreacjonistow.html? fbclid= IwAR3waqJgG4TRFe0xuqEa89U7kww9DfqI4mXNEPt-RptwaNnP08Taa6ZsodE.
} 
sposób, aby wykluczała całkowicie udział Boga w powstaniu świata, redukując jego genezę do serii następujących po sobie przypadków" ${ }^{84}$. Teoria ewolucji (nie zaś hipoteza) kojarzona jest przez uczniów z lekcją biologii, gdyż opisuje zjawiska $\mathrm{z}$ obszaru przyrody ożywionej, więc nagły przeskok do zagadnienia powstania świata powoduje myślowy zamęt. Co więcej, kreacjonizm jest stanowiskiem filozoficzno-teologicznym, zatem można pokazać jego wartość niezależnie od jakichkolwiek przyrodniczych hipotez dotyczących powstania świata. Autorzy tekstu słusznie, choć nieudolnie, starają się uwypuklić słabość materialistycznego ewolucjonizmu, ale nie rozumieją roli przypadku w procesach przyrody, traktując go jako swoistego rywala działającego Boga. $Z$ jednej strony z treści tej jednostki wynika chęć obrony kreacjonizmu: „Ewolucjonizm antykreacyjny, propagujący założenia ateistyczne czy naturalistyczne, jest nie do przyjęcia" ${ }^{85}$. Z drugiej strony kreacjonizm - za wątpliwej jakości tekstem z Youcat - definiowany jest jako „pogląd postrzegający Księgę Rodzaju jako protokół z przebiegu zdarzeń i twierdzący, że Bóg sam przez bezpośredni akt stworzyt ziemię za jednym razem" $" 86$ (podkr. M. S.). Czy w takim razie - przy prezentowanym przez autorów założeniu, że biblijne opisy stworzenia nie są opisem historii naturalnej — kreacjonizm występuje wyłącznie w takiej formie i należy go odrzucić?

Odpowiedź twierdząca na powyższe pytanie wynika także z poradnika metodycznego do omawianego podręcznika. Nauczyciele przygotowujący analizowaną jednostkę lekcyjną otrzymują następujące wskazania:

Katecheta pyta uczniów o ich wiedzę na temat teorii ewolucji: Jakie argumenty
świadczą za taką hipotezą? [...] Zwraca uwagę, że brakuje niezbitych dowodów
na ewolucje [...]. Teorią konkurencyjna dla ewolucjonizmu jest kreacjonizm,
czyli przekonanie, że Bóg stwarzał ziemię i organizmy żywe bezpośrednio, w
formie już ukształtowanej. Temu pogládowi towarzyszy dostowne interpreto-
wanie biblijnego opisu stworzenia. Spór o genezę życia na ziemi jest wciąż
żywy. (Podkr. M. S.)

Cytowane słowa świadczą o nieznajomości teorii ewolucji oraz filozofii nauki. Autorzy sugerują uczniom, że ewolucjonizmu nie da się pogodzić $\mathrm{z}$ kreacjonizmem, a ten ostatni występuje jedynie w ujęciu sprzecznym z nauczaniem Kościoła katolickiego na temat poprawnej interpretacji biblij-

\footnotetext{
${ }^{84}$ Świadczę o Jezusie w świecie, 22.

${ }^{85}$ Tamże.

${ }^{86}$ Tamże, 23.

${ }^{87}$ Świadczę o Jezusie w świecie, 50.
} 
nych opisów stworzenia. W to miejsce należałoby zaprezentować kreacjonizm zgodny z katolicką doktryną o Bogu Stwórcy, która nie ujmuje pierwszych rozdziałów Księgi Rodzaju w kategoriach historycznych.

Jeszcze bardziej nieodpowiednią formą przekazu treści religijnych jest promocja teorii inteligentnego projektu, która w kontekście sporu ewolucjonizm - kreacjonizm przedstawiana jest jako złoty środek, prowadzący od refleksji nad przyrodą do konstatacji o istnieniu i działaniu Boga. Katechetę zachęca się do wykorzystania następującej analogii: „Można posłużyć się ilustracją zegarka znalezionego na wrzosowisku - skoro jest to urządzenie składające się ze współgrających ze sobą mechanizmów, nie może być on rezultatem działania nierozumnych, przypadkowych i naturalnych przyczyn. Projekt widoczny w konstrukcji zegarka domaga się istnienia inteligentnego projektanta. Skoro tak to przyroda ożywiona - z o wiele bardziej skomplikowanymi mechanizmami - też nie może być wynikiem przypadku, ale dziełem inteligentnego Projektanta" ${ }^{\prime 8}$. Takie wnioskowanie - zaproponowane przed ponad 200 laty przez anglikańskiego teologa W. Paleya - wielokrotnie poddawano merytorycznej krytyce, w ramach której podkreślano, że prowadzi ona co najwyżej do wniosku o istnieniu koordynatora parametrów przyrody, nie zaś Boga ukazywanego przez chrześcijańskie Objawienie $^{89}$. Autorzy omawianej jednostki lekcyjnej bez żadnego komentarza wyliczają następujące argumenty mające świadczyć o wartości teorii inteligentnego projektu:

Istnienie życia (naukowcy nie potrafią stworzyć żywej komórki), [...] precyzyjne dostrojenie Wszechświata (w astrofizyce wiele fundamentalnych stałych przyrody jest dokładnie takich, że na Ziemi może istnieć życie w takiej postaci, jak znamy, np. odległość Ziemi od Słońca), [...] Wielki Wybuch, czyli istnienie początku Wszechświata, $[\ldots]$ niezwykle precyzyjny zapis $\mathrm{DNA}^{90}$.

Wymienione kwestie doczekały się szczegółowej analizy przyrodniczofilozoficznej, która podważa wiele aspektów argumentacji zwolenników teorii inteligentnego projektu ${ }^{91}$. Brak kompetencji redaktorów książki (a może tylko per fas et nefas bronienie przedstawionych tez) uwidacznia się także w

\footnotetext{
${ }^{88}$ Tamże.

${ }^{89}$ Por. np. Stanisław JAROMI, „Kościół a ewolucja — zasady dialogu”, Roczniki Filozoficzne 60, nr 4 (2012): 227.

${ }^{90}$ Świadczę o Jezusie w świecie (Poradnik metodyczny), 50-51.

${ }^{91}$ Jerry A. CoYNe, „Teoria inteligentnego projektu. Wiara, która nie chce się ujawnić”, w: Brockman, Nauka a kreacjonizm, 15-34; Michał Heller, Filozofia przypadku. Kosmiczna fuga z preludium i coda (Kraków: Copernicus Center Press, 2011), 129-186.
} 
końcowej partii jednostki lekcyjnej przy wykazie proponowanej literatury ${ }^{92}$. Zawiera on wyłącznie pozycje wydane pomiędzy 1950 a 1989 rokiem, a na liście znajduje się publikacja J. W. G. Johnsona pt. Na bezdrożach teorii ewolucji ${ }^{93}$, która spotkała się z bardzo negatywnymi recenzjami ${ }^{94}$.

Autorzy jednostki lekcyjnej sugestywnie zatytułowanej „Mój «brat»szympans - czyli rzecz o ewolucji” we wprowadzeniu zachęcają uczniów do refleksji: „Może zastanawialiście się nad tym, jak powstał świat, skąd wziął się człowiek, jak dokonywał się ich rozwój. Ciekawi nas to, czy rzeczywiście u początków istnienia świata, człowiek byt podobny do matpy lub tez byt matpa [podkr. M. S.]. A jeśli nawet był małpą, to w którym momencie rozwoju otrzymał dar duszy. Tego typu pytania często pojawiają się w naszych umysłach. Każdy człowiek chce przecież odkryć swoją tożsamość"95. W rubryce pt. „Zastanów się” jedno z pytań brzmi następująco: „Zastanów się, czy dobrze byś się poczuł, gdybyś odkrył, że twoim prapradziadkiem jest szympans" "96. Pomijając wątpliwej jakości zabieg erystyczny zawarty w ostatnim zdaniu, należy podkreślić, że zgodnie ze współczesną wiedzą przyrodniczą u początków istnienia świata nie było ani żadnych małp ani żadnych istot żywych, zaś pierwsze hominidy pojawiły się na Ziemi ok. siedmiu milionów lat temu, czyli po kilkunastu miliardach lat od Wielkiego Wybuchu.

Na końcu tej jednostki lekcyjnej znajduje się część pt. „Kościół naucza”, której autorzy na początku podkreślają autonomię oraz odmienne kompetencje nauki i religii a także wzajemne uzupełnianie się tych perspektyw poznawczych:

Czy można być przekonanym o istnieniu ewolucji $i$ wierzyć $w$ Stwórcę? Tak. Wiara wychodzi naprzeciw wynikom badań i hipotezom nauk przyrodniczych. Teologia nie ma żadnych uprawnień w naukach przyrodniczych. Nauki przyrodnicze nie mają żadnych uprawnień $\mathrm{w}$ teologii. Nauki przyrodnicze nie mogą dogmatycznie wykluczyć, że w stworzeniu istnieje celowy proces rozwoju. Wiara z kolei nie może zdefiniować, jak konkretnie przebiega ten proces rozwoju

\footnotetext{
${ }^{92}$ Świadczę o Jezusie w świecie (Poradnik metodyczny), 58.

${ }^{93}$ J. W. G. Johnson, Na bezdrożach teorii ewolucji, tłum. Jan Kempski (Warszawa-Struga: Michalineum, 1989).

${ }^{94}$ Por. Andrzej JermaczeK, „Rec. Johnson J. W. G. 1989. Na bezdrożach teorii ewolucji. Wydaw. Michalineum, Warszawa-Struga”, Lubuski Przegląd Przyrodniczy 1, nr 3 (1990): 58-59; Karol SABATH, „Jak zostałem fundamentalistą antyreligijnym”, Kosmos 42, nr 3-4 (1993): 687-714.

${ }^{95}$ Być świadkiem Zmartwychwstałego w świecie (Podręcznik do nauki religii dla II klasy liceum i technikum), red. Piotr Pierzchała (Warszawa: Wydawnictwo Katechetyczne, 2013), 31.

${ }^{96}$ Tamże, 33.
} 
natury. Chrześcijanin może uznać teorię ewolucji za pomocny model wyjaśniajacy, uważając jednak, by nie popetnić błędu ewolucjonizmu, który postrzega człowieka jako przypadkowy efekt procesów biologicznych [podkr. M. S.]. EWOLUCJA zakłada, że coś, co istnieje, może się rozwijać. Nie odpowiada jednak na pytanie, skąd to „coś” pochodzi. Nie da się też na gruncie biologii udzielić odpowiedzi na pytanie o sens, istotę, godność, zadanie i przyczynę świata i ludzi. Podobnie jak zjednej strony ewolucjonizm, $z$ drugiej strony KREACJONIZM sa przesadne [podkr. M. S.]. Odrzucając ewolucję, niektórzy ludzie naiwnie przyjmują dosłownie dane dotyczące wieku ziemi i sześciu dni stworzenia świata ${ }^{97}$.

Druga część cytowanego tekstu świadczy o bardzo wąskim rozumieniu zarówno ewolucjonizmu, jak i kreacjonizmu. Sformułowanie, że „są przesadne" ujawnia słabość języka przekazu ważnych treści. Brakuje informacji o istnieniu teistycznego ewolucjonizmu, kreacjonizm zaś bezpodstawnie utożsamiany jest $\mathrm{z}$ nurtami interpretującymi biblijne opisy stworzenia $\mathrm{w}$ kategoriach historycznych.

Traktowanie przywołanych fragmentów pierwszej księgi Pisma św. jak przekazu historii stanowi częsty błąd popełniany przez autorów podręczników, mimo, że deklaratywnie wyrażają oni świadomość doktryny Kościoła katolickiego na temat właściwego rozumienia opisów stworzenia. Problem ten pojawia się nie tylko $\mathrm{w}$ połączeniu $\mathrm{z}$ cytowanymi wyżej pseudonaukowymi konstatacjami o przechodzeniu świata ze stanu pierwotnego chaosu do absolutnego porząaku, ale także w bezpośrednim odniesieniu do działania Stwórcy. W jednostce lekcyjnej pt. „Wszechświat - Boski porządek” czytamy:

Bóg, stwarzając wszechświat, wyposażył go w konkretne prawa i zależności, umożliwiające jego funkcjonowanie. To co stworzył, uczynił doskonale. Jego dzieło jest uporządkowane. Nie ma w nim śladów żadnego bałaganu, anarchii czy przypadkowości. Wszystko jest dopracowane $i$ współgra jedno z drugim [podkr. M. S.]. Nam, ludziom, nieco trudniej wprowadzić określony porządek w swoje życie i swój świat. Nieraz ulegamy chaosowi, tracąc czas, a niejednokrotnie także ktoś inny jest przyczyną bałaganu w naszym życiu ${ }^{98}$.

W innym podręczniku, podczas analizy jednostki lekcyjnej „Zamysł Boga względem człowieka - zostaliśmy stworzeni do szczęścia”, jej autorzy $\mathrm{z}$ jednej strony akcentują, że w opisie biblijnym nie chodzi „o wskazanie konkretnego miejsca, ale ukazanie obrazu świata stworzonego przez Boga, w którym człowiek, żyjąc w bliskości Stwórcy i w harmonii z otaczającą go

\footnotetext{
97 Tamże, 34

98 Tamże, 52.
} 
przyrodą, mógł zaznać szczęścia”99. Z drugiej strony czytamy: „W pierwotnym stanie człowiek nie tyle dążył do szczęścia, ile już był szczęśliwy" ${ }^{100}$. Konkluzja pozostawia uczniów z jednoznacznym przekonaniem o istnieniu w przeszłości idealnego miejsca dla ludzkiej egzystencji: „Majac na uwadze chociażby fakt, że już sam ogród ze względu na znajdujaca się w nim roślinność oraz liczne źródta wody byt dla ludzi Wschodu symbolem bogactwa i szczęśliwego życia, widzimy, że Bóg w swej dobroci stworzyt dla człowieka idealne miejsce [podkr. M. S.]. W tym miejscu człowiek mógł przebywać ze swym Stwórcą — źródłem wszelkiego dobra, miłości i szczęścia"101.

Wbrew tytułowi „Poemat o stworzeniu świata”, sugestię o fizycznym istnieniu stanu absolutnej harmonii sugestywnie wyraża tekst jednostki katechetycznej, zawartej w podręczniku z wydawnictwa Jedność: „Bóg przy stwarzaniu kieruje się mądrością, nadając światu ład i harmonię: wszystkie jego elementy są ze sobą powiązane i służą sobie nawzajem" ${ }^{102}$. Kilka stron dalej czytamy:

Biblijny opis stworzenia ani nie neguje teorii ewolucji, ani też jej nie potwierdza. Po prostu nie zajmuje się tym zagadnieniem. Autor natchniony pragnie nam przekazać tylko prawdy o zbawieniu. Biblia nie jest traktatem przyrodniczym, lecz księgą religijną. Opisywanie sposobu rozwijania się stworzonej przez Boga materii należy do naukowców. Teoria ewolucji nie zaprzecza idei stworzenia wszystkiego przez Boga, a więc chrześcijanin może przyjąć tę teorię. Aby coś mogło ewoluować, musi najpierw zaistnieć [podkr. M. S.]. Rozwój wszystkiego, co jest, potwierdza istnienie Istoty rozumnej, kierującej wszystkim w myśl odwiecznie ustalonych przez Nią praw przyrody. Zajmując się człowiekiem, można przyjąć ewolucję tylko w odniesieniu do jego ciała. Papież Pius XII mówi w swoim nauczaniu, że ludzkie dusze zostały stworzone bezpośrednio przez Boga.

Widać więc zrozumienie dla autonomii poszczególnych perspektyw poznawczych, ale także bezkrytyczne słowa o tym, że rozwój wszystkiego, co jest, jednoznacznie potwierdza istnienie i działanie Boga. Takie ujęcie zupełnie pomija niezmiernie istotny problem zła i cierpienia w świecie oraz związanych z tym pytań dotyczących obecności i aktywności Boga w sytuacjach skrajnego bólu niewinnych osób. Jeśli autorzy sugerują, że zło, cier-

\footnotetext{
${ }^{99}$ Aby nie ustać $w$ drodze (Podręcznik do nauki religii dla II klasy gimnazjum), red. Jan Szpet, Danuta Jackowiak (Poznań: Wydawnictwo św. Wojciecha, 2013), 10.

${ }^{100}$ Tamże.

${ }^{101}$ Tamże, 11.

${ }^{102}$ Na drogach wiary (Podręcznik do nauki religii dla II klasy liceum i technikum), red. Jarosław Czerkawski, Elżbieta Kondrak, Bogusław Nosek (Kielce: Jedność, 2013), 18.
} 
pienie i śmierć istniejące w świecie pojawiły się wskutek grzechu pierwszych ludzi to by znaczyło, że literalistycznie rozumiane są biblijne opisy stworzenia. Mimo otwartości na przyjęcie teorii ewolucyjnego pochodzenia ludzkiego ciała oraz deklaracji, że Pismo św. to nie księga przyrody, autorzy rzeczywiście pozostawiają „uchyloną furtkę” do szukania w opisach stworzenia człowieka historycznych zdarzeń: „Rozumna i nieśmiertelna dusza nie może pochodzić od zwierząt. Nie jest jednak wykluczone, że planując zaistnienie człowieka, Bóg obdarował nieśmiertelną duszą któreś $\mathrm{z}$ istniejących już zwierząt, dzięki czemu stało się ono istotą wolną i rozumną. Być może o takiej chwili opowiada Księga Rodzaju"103(podkr. M. S.).

\section{ZAKOŃCZENIE}

Nie da się udowodnić, że antyewolucyjni kreacjoniści mieli bezpośredni wpływ na treści zawarte $\mathrm{w}$ analizowanych książkach do nauki religii, nawet przy wzięciu pod uwagę przedstawionego w artykule zintensyfikowania ich działań od połowy 2006 r. Biorący wzór ze znanych poglądów Davida Hume'a sceptycy stwierdzą, że pomiędzy publikacjami czy publicznymi wypowiedziami skrajnych kreacjonistów a tekstami zawartymi w zredagowanych w kolejnych latach jednostkach katechetycznych można wykazać wyłącznie następstwo czasowe. Stawiam jednak tezę, że w omawianym zakresie istnieje związek przyczynowo-skutkowy. Nawet jeśli nie da się go w kategoriach bezpośredniego wpływu pokazać, z przedstawionych wyżej tekstów widać, jak wiele aspektów antyewolucyjnego kreacjonizmu zostało włączonych do podręczników i poradników katechetycznych.

Niektórym autorom cytowanych publikacji mogło się wydawać, że podważając zaufanie do wyników nauk przyrodniczych przyczyniają się do wzmacniania religijnego przekazu. Obniżanie rangi ewolucjonizmu jako sposób na uwypuklenie wartości kreacjonizmu stanowi znany zabieg retoryczny, który stosowany jest nie tylko w omawianym kontekście. Logika myślenia zawarta w formule ,im gorzej dla nauki, tym lepiej dla religii” świadczy o traktowaniu tych obszarów jako konkurencyjnych albo nawet wzajemnie wykluczających się dziedzin poznania. Nie ma to nic wspólnego ze współczesną doktryną Kościoła katolickiego, nauczającego o relacji Fides et ratio ${ }^{104}$, oraz

\footnotetext{
103 Tamże, 26.

${ }^{104}$ Jan Pawee II, Fides et ratio (Vaticano, 1988).
} 
$\mathrm{z}$ wielowiekową tradycją chrześcijańską, wyrażoną w anzelmiańskim haśle fides quaerens intellectum ${ }^{105}$.

Zwracając uwagę na przejawy antyewolucyjnego kreacjonizmu w publikacjach katechetycznych, podkreśliłem, że w niejednej jednostce lekcyjnej mieszają się one $\mathrm{z}$ merytorycznym przekazem, uwzględniającym nie tylko dobrze ujęte wątki teologiczne, ale także fachową wiedzę przyrodniczą oraz przygotowanie filozoficzne. Stanowczo za dużo jest jednak treści zawierających podstawowe błędy ( $\mathrm{z}$ każdej $\mathrm{z}$ wymienionych $\mathrm{w}$ poprzednim zdaniu dziedzin), opartych na nieaktualnym obrazie świata ${ }^{106}$ i zredagowanych w taki sposób, który trudno uznać za pozytywy wkład w budowanie relacji między nauką a wiarą religijną. Za mało miejsca poświęca się wartościowym nurtom kreacjonizmu oraz naukowym postaciom ewolucjonizmu.

Kreacjonizm zbyt często utożsamiany jest $\mathrm{z}$ tymi jego odmianami, które w języku angielskim określane są mianem creationism. Takie zawężenie znaczeniowe, niestety mocno zakorzenione w anglojęzycznej literaturze, powstało wskutek skupiania uwagi na tych środowiskach kreacjonistycznych, które - zwłaszcza w USA — od ponad 100 lat znane są z historycznego interpretowania biblijnych opisów stworzenia i/lub z krytyki teorii ewolucji. Konsekwencją długofalowego oddziaływania wspomnianych gremiów stało się pozbawianie w prowadzonych dyskusjach znaczenia tej formy kreacjonizmu, która pozostaje cennym przykładem filozoficzno-teologicznej refleksji na temat Boga Stwórcy, otwartej na współczesną hermeneutykę biblijną

${ }^{105} \mathrm{~W}$ tym kontekście warto sięgnąć po szczegółowe opracowania na temat specyfiki poszczególnych modeli relacji nauka - wiara (religia). Por. np. Willem B. DreEs, Nauka wobec wiary. Spory, debaty, konteksty, tłum. Krzysztof Skonieczny (Kraków: Copernicus Center Press, 2016); Wojciech Kотошicz, „Józefa Życińskiego meta-przedmiotowe ujęcie relacji między nauką a religią”, Roczniki Filozoficzne 60, nr 4 (2012): 249-260; Znak, nr 760 (2018). Istotne są tu także epistemologiczne aspekty relacji religii z nauką, o których pisałem w: Ewolucjonizm chrześcijański, 21-44.

${ }^{106}$ Michał Heller twierdzi: „W katechezie szkolnej nie ma współczesnego obrazu świata. Między innymi dlatego młodzież rezygnuje z lekcji religii [...]. Młodzież katechezę traktuje jak fantazję" (https://tischner.pl/ks-heller-nauka-pomaga-teologii/). Por. też: Michał HeLler, „Naukowy obraz świata a zadanie teologa”, w: Obrazy świata w teologii $i$ w naukach przyrodniczych, red. Michał Heller, Stanisław Wszołek, Stanisław Budzik (Tarnów: Biblos, 1996), 13-27. Interesujące poznawczo byłoby zrekonstruowanie obrazu świata, zakładanego przez antyewolucyjnych kreacjonistów oraz autorów podręczników do katechezy w Polsce. Taka analiza hermeneutyczna wykracza jednak znacznie poza ramy niniejszego artykułu i domaga się odrębnego opracowania. Wnikliwe badania warto by także podjąć w perspektywie ostatniego z cytowanych wyżej zdań ks. Hellera. Jego mocna konstatacja o traktowaniu lekcji religii w kategoriach fantazji kieruje uwagę nie tylko na problem intelektualnych, lecz również psychospołecznych skutków edukacji religijnej opartej na przestarzałym obrazie świata. 
oraz aktualną wiedzę przyrodniczą ${ }^{107}$. Nie widać powodów do kopiowania tego scenariusza $\mathrm{w}$ Polsce i spychania na margines ambitnych koncepcji teistycznych, rozwijających na przykład ideę creatio continua czy teorię działania Boga poprzez prawa przyrody, także na przełomowych etapach rozwoju przyrody.

Ewolucjonizm kojarzony jest głównie ze skrajnym naturalizmem, który reprezentowany jest przez scjentystów. Traktują oni nauki przyrodnicze jako jedyne źródło poznania świata, wykluczając możliwość realnego istnienia jakiejkolwiek rzeczywistości duchowej. Takie przejawy absolutyzacji nauki powiązane są niejednokrotnie $\mathrm{z}$ - bliską tzw. nowym ateistom - mentalnością ,im gorzej dla religii, tym lepiej dla nauki”, stanowiącą lustrzane odbicie nakreślonej nieco wyżej logiki myślenia niektórych kreacjonistów. Zamiast koncentrowania się na ideologicznych wersjach ewolucjonizmu, warto by wnikliwiej przybliżyć uczniom te jego aspekty, które nie tylko nie stanowią żadnego zagrożenia dla wiary religijnej, ale mogą pomóc w jej rozwinięciu, między innymi po to, by zestawienie treści podawanych na lekcjach religii i przedmiotach przyrodniczych nie było odbierane w kategoriach alternatywy rozłącznej ${ }^{108}$. Rozumiał to doskonale Jan Paweł II, pisząc w przesłaniu skierowanym do dyrektora Obserwatorium Watykańskiego, że teologia musi dziś ,pozostawać w żywej wymianie z nauką, tak jak zawsze miało to miejsce $\mathrm{w}$ stosunku do filozofii i innych form wiedzy. Teologia w tym czy innym stopniu powinna powoływać się na odkrycia nauki, na ile jej główne zainteresowania skupiają się wokół osoby ludzkiej, granic wolności, możliwości wspólnoty chrześcijańskiej, natury wiary oraz zrozumiałości przyrody i historii. Żywotność i znaczenie teologii dla ludzkości będą w głęboki sposób odzwierciedlone w jej zdolności do przyjęcia tych odkryć" ${ }^{109}$.

Papież wymienia konkretne obszary nauk przyrodniczych, które mogą wzbogacić przekaz treści religijnych: współczesna kosmologia ma coś do zaofiarowania chrześcijańskiej refleksji nad stworzeniem a perspektywa ewolucyjna rzuca światła na antropologię teologiczną, rozumienie osoby ludzkiej jako imago Dei, zagadnienia chrystologiczne, a nawet na rozwój samej

${ }^{107}$ Por. Michał Heller, „Jak uczyć o stworzeniu?, Tarnowskie Studia Teologiczne 32, nr 1 (2013): 115-120.

${ }^{108}$ Por. Józef Życiński, Bóg i stworzenie. Zarys teorii ewolucji (Lublin: Gaudium, 2011), 12. Ta publikacja - jak czytamy we wstępie — została napisana jako „pomoc dla prowadzących katechezę" (s. 11).

${ }^{109}$ JAN PAwEe II, „Posłanie do o. George'a V. Coyne’a, dyrektora Obserwatorium Watykańskiego (Watykan 1.VI.1988)", w: Tadeusz Sierotowicz, Nauka a wiara - przestrzeń dialogu. Obrazy świata jako przestrzeń dialogu pomiędzy nauka a teologia (Tarnów: Biblos, 1997), 269. 
doktryny chrześcijańskiej. Zagłębianie się w takie kwestie wymaga intensywnego dialogu ze współczesną nauką, którego — zdaniem Jana Pawła II brakuje wśród ludzi zaangażowanych $\mathrm{w}$ badania teologiczne i nauczanie teologii ${ }^{110}$. Widać to wyraźnie $\mathrm{w}$ analizowanych przeze mnie podręcznikach katechetycznych. Przywołane wyżej teksty świadczą o tym, że ich redaktorzy nie konsultowali zagadnień na styku religii i nauki ze specjalistami $\mathrm{z}$ różnych dziedzin wiedzy, zwłaszcza $\mathrm{z}$ tymi reprezentantami Kościoła katolickiego, którzy od lat zajmują się problematyką interdyscyplinarną, obejmującą takie kwestie jak powstanie świata czy antropogeneza. O docenianie tych osób apelował papież w cytowanym dokumencie, podkreślając, że „ci członkowie Kościoła, którzy są aktywnymi naukowcami, lub, w pewnych szczególnych przypadkach, zarówno naukowcami jak i teologami, mogliby podsuwać nowe pomysły i ukazywać środki. Mogą oni również prowadzić bardzo potrzebną posługę na rzecz innych ludzi, borykających się nad zintegrowaniem świata religii i świata nauki w swoim własnym, intelektualnym i duchowym życiu"111. Uwzględnienie słów Karola Wojtyły przez wszystkich zaangażowanych w edukację religijną w Polsce byłoby ważnym znakiem naśladowania jego intelektualnej otwartości.

\section{BIBLIOGRAFIA}

Aby nie ustać w drodze (Podręcznik do nauki religii dla II klasy gimnazjum). Red. Jan Szpet, Danuta Jackowiak. Poznań: Wydawnictwo św. Wojciecha, 2013.

BAKER, Jason M. „Adaptive speciation. The role of natural selection in mechanisms of geographic and non-geographic speciation". Studies in History and Philosophy of Science Part C: Studies in History and Philosophy of Biological and Biomedical Sciences 36, nr 2 (2005): 303-326.

Brockman, John, red. Nauka a kreacjonizm. O naukowych uproszczeniach teorii inteligentnego projektu. Tłum. Dariusz Sagan, Sławomir Piechaczek. Warszawa: CIS, 2007.

Być świadkiem Zmartwychwstałego w świecie (Podręcznik do nauki religii dla II klasy liceum i technikum). Red. Piotr Pierzchała. Warszawa: Wydawnictwo Katechetyczne, 2013.

Chaberek, Michał. Kościól a ewolucja. Warszawa: Fronda, 2012.

Chaberek, Michał, Tomasz Rowiński. Stworzenie czy ewolucja. Dylemat katolika. Warszawa: Fronda, 2014.

Coyne, Jerry A., H. Allen OrR. Speciation. Sunderland, MA: Sinauer, 2004.

CoYne, Jerry A. „Teoria inteligentnego projektu. Wiara, która nie chce się ujawnić”. W: BrockMAN, Nauka a kreacjonizm, 15-34.

\footnotetext{
${ }^{110}$ Tamże, 270.

${ }^{111}$ Tamże, 270-271.
} 
Czerkawski, Jarosław, Elżbieta Kondrek, Bogusław Nosek, red. Na drogach wiary (Podręcznik do nauki religii dla II klasy liceum i technikum). Kielce: Jedność 2013.

Drees, Willem B. Nauka wobec wiary. Spory, debaty, konteksty. Tłum. Krzysztof Skonieczny. Kraków: Copernicus Center Press, 2016.

Dziadosz, Dariusz. Tak było na początku. Izrael opowiada swoje dzieje. Przemyśl: Wydawnictwo Archidiecezji Przemyskiej, 2011.

„Dziekani: ewolucja istnieje, a Giertych i Orzechowski kompromitują kraj”. Wirtualna Polska, 25.10.2006. Dostęp 29.08.2020. https://wiadomosci.wp.pl/dziekani-ewolucja-istnieje-agiertych-i-orzechowski-kompromituja-kraj-6037394693579393a.

EhrLich, Paul R. Human Natures. Washington, DC: Shearwater Books, 2000.

Fenchel, Tom. The Origin and Early Evolution of Life. Oxford - New York: OUP, 2002.

FutuYma, Douglas J. Ewolucja. Warszawa: Wydawnictwa UW, 2008.

GIERTYCh, Maciej. „Creationism, evolution. Nothing has been proved”. Nature, nr 444 (2006): 265. https://www.nature.com/articles/444265d

GierTych, Maciej. „Dinozaury żyły w czasach ludzi”. Wprost, 23.10.2006. Dostęp 18.08.2020. https://www.wprost.pl/96230/maciej-giertych-dinozaury-zyly-w-czasach-ludzi.html.

Giertych, Maciej. „Nauka na służbie ideologii.” Opoka w kraju 46 (2003): 6-8. Dostęp 20.08.2020. http://opoka. giertych.pl/owk46.htm.

Gould, Stephen J. The Structure of Evolutionary Theory. Cambridge, MA: Harvard University Press, 2002.

HaJduk, Zygmunt. Ogólna metodologia nauk. Lublin: Wydawnictwo KUL, 2001.

Hazen, Robert M. Genesis. The Scientific Quest for Life's Origin. Washington, DC: Joseph Henry Press, 2005.

Heller, Michał. Nauka i Teologia - niekoniecznie tylko na jednej planecie. Kraków: Copernicus Center Press, 2019.

Heller, Michał. „Jak uczyć o stworzeniu?”. Tarnowskie Studia Teologiczne 32, nr 1 (2013): $115-120$.

Heller, Michał. Filozofia przypadku. Kosmiczna fuga z preludium i codą. Kraków: Copernicus Center Press, 2011.

Heller, Michał. „Naukowy obraz świata a zadanie teologa”. W: Obrazy świata w teologii i w naukach przyrodniczych, red. Michał Heller, Stanisław Wszołek, Stanisław Budzik, 13-27. Tarnów: Biblos 1996

JAN Pawę II. „Magisterium Kościoła wobec ewolucji (Przesłanie do członków Papieskiej Akademii Nauk, Watykan 22.X.1996)". Osservatore Romano 18, nr 1 (1997): 18-19.

JAN PAwEe II. „Posłanie do o. George'a V. Coyne'a, dyrektora Obserwatorium Watykańskiego (Watykan 1.VI.1988)". W: Tadeusz Sierotowicz, Nauka a wiara - przestrzeń dialogu. Obrazy świata jako przestrzeń dialogu pomiędzy nauka a teologia, 262-273. Tarnów: Biblos, 1997.

Jaromi, Stanisław. „Kościół a ewolucja — zasady dialogu”. Roczniki Filozoficzne 60, nr 4 (2012): 219-232.

JermaczeK, Andrzej. „Rec. Johnson J. W. G. 1989. Na bezdrożach teorii ewolucji. Wydaw. Michalineum, Warszawa-Struga". Lubuski Przeglad Przyrodniczy 1, nr 3 (1990): 58-59.

Jezus uczy i zbawia (Podręcznik do nauki religii dla I klasy gimnazjum). Red. Zbigniew Marek, Andrzej Hajduk, Janusz Mółka, Anna Waliluk. Kraków: WAM, 2012. 
Johnson, J. W. G. Na bezdrożach teorii ewolucji. Tłum. Jan Kempski. Warszawa-Struga: Michalineum, 1989.

„Katoliccy filozofowie: nie ma konfliktu między ewolucją a stworzeniem”. eKAI, 20.10.2006. Dostęp 2.09.2020. https://ekai.pl/katoliccy-filozofowie-nie-ma-konfliktu-miedzy-ewolucja-a-stworzeniem.

Kотошicz, Wojciech. „Józefa Życińskiego meta-przedmiotowe ujęcie relacji między nauką a religią". Roczniki Filozoficzne 60, nr 4 (2012): 249-260.

KowALSKI, Marian. “Argumenty kreacjonistów? Obal je wszystkie”. totylkoloteria.pl, 11.03.2018. Dostęp 2.09.2020. https://www.totylkoteoria.pl/2018/03/argumenty-kreacjonistow.html? fbclid=IwAR3waqJgG4TRFe0xuqEa89U7kww9DfqI4mXNEPt-RptwaNnP08Taa6ZsodE.

KrawCzyK, Józef F. Człowiek nie zaistniał przez przypadek. Przegrałeś Darwinie!, Sandomierz: Wydawnictwo Diecezjalnie, 2003.

„Kto podważa teorię Darwina”. Nauka w Polsce, 17.10.2006. Dostęp 20.08.2020. https:// naukawpolsce.pap.pl/aktualnosci/news\%2C25674\%2Ckto-podwaza-teorie-darwina.html.

LuisI, Pier Luigi. The Emergence of Life. From Chemical Origins to Synthetic Biology. Cambridge: CUP, 2006.

Marek, Zbigniew, Andrzej Hajduk, Janusz MóŁKa, Anna Waliluk, red. Jezus uczy i zbawia (Podręcznik do nauki religii dla I klasy gimnazjum). Kraków: WAM, 2012.

MARYNIARCZYK, Andrzej. „Dlaczego kreacjonizm?”. W: Ewolucjonizm czy kreacjonizm (Przyszłość cywilizacji Zachodu), red. Piotr Jaroszyński, 41-91. Lublin: Fundacja Lubelska Szkoła Filozofii Chrześcijańskiej, 2008.

MaryniarczyK, Andrzej. Dlaczego stworzenie „ex nihilo”. Teoria metafizycznego kreacjonizmu. Lublin: Polskie Towarzystwo Tomasza z Akwinu, 2018.

Moje miejsce w świecie (Podręcznik do nauki religii dla II klasy szkół ponadgimnazjalnych). Red. Jan Szpet, Danuta Jackowiak. Poznań: Wydawnictwo św. Wojciecha, 2013.

Na drogach wiary (Podręcznik do nauki religii dla II klasy liceum i technikum). Red. Jarosław Czerkawski, Elżbieta Kondrak, Bogusław Nosek. Kielce: Jedność, 2013.

NikLewicz, Konrad. „Giertych chce zakazać Darwina w szkołach”. Gazeta.pl, 13.10.2006. Dostęp 20.08.2020, https://wiadomosci.gazeta.pl/wiadomosci/1,114873,3682091.html.

PABJAn, Tadeusz. „Czy nauka dowodzi istnienia Boga? Naukowa apologetyka Piusa XII”. Studia Philosophiae Christianae 45, nr 2 (2009): 277-294.

PAjewski, Mieczysław. „Meandry sporów o pochodzenie (cz. 5)”. Idź pod prąd, nr 13 (sierpień 2005): 8-9.

PaPieska Komisja Biblijna. Interpretacja Pisma Świętego w Kościele (Przemówienie Ojca Świętego Jana Pawła II oraz Dokument Papieskiej Komisji Biblijnej). Tłum. Kazimierz Romaniuk. Poznań: Pallottinum, 1994.

PezDA, Aleksandra. „Wiceminister edukacji: Poradzimy sobie bez tolerancji”. Gazeta.pl, 14.10. 2006. Dostęp 21.08.2020. https://wiadomosci.gazeta.pl/wiadomosci/ 1,114873, 3684136.html.

PIUS XII. Encyklika o pewnych fałszywych poglądach zagrażających podstawom nauki katolickiej Humani generis (12.08.1950). Vaticano: LEV, 1950.

PIwowar, Andrzej. „Biblijny opis stworzenia świata i człowieka w odniesieniu do nauk przyrodniczych". W: Naukowy a religijny obraz początku wszechświata i człowieka. Perspektywy dialogu, red. Jacek Golbiak, Karol Jasiński, Wojciech Kotowicz, 49-95. Wydział Teologii UWM: Olsztyn, 2015.

Polak-PaŁkiewicz, Ewa. „Ewolucja — obłok wiedzy czy ideologii”. Niedziela 46 (2006): 26. Dostęp 17.08.2020. https://www.niedziela.pl/artykul/80613/nd/Ewolucja---oblok-wiedzyczy-ideologii. 
Rauchruss, Horst. Chemical Evolution and the Origin of Life. Berlin: Springer, 2008.

RiBas de Pouplana Lluis, red. The Genetic Code and the Origin of Life. New York: Academic/Plenum, 2004.

SAвAтH, Karol. „Jak zostałem fundamentalistą antyreligijnym”. Kosmos 42, nr 3-4 (1993): 687714.

Safran, Rebecca J., Patrik Nosil. Speciation. The Origin of New Species, "Nature Education Knowledge" 3 (2012): 17.

Schwartz, Jeffrey H. Sudden Origins. Fossils, Genes, and the Emergence of Species. New York: Wiley, 1999.

SeCKвасH, Joseph, red. Origins. Genesis, Evolution and Diversity of Life. New York: Kluwer Academic Publishers, 2004.

ShubIN, Neil H. „«Wielkie» przejście”. W: BRockman, Nauka a kreacjonizm, 95-105.

SKA, Jean-Louis. Introduction to Reading the Pentateuch. Tłum. Pascale Dominique. Winona Lake, IN: Eisenbrauns, 2006.

SŁomKa, Marek. Działanie Boga w świecie. Analiza filozoficzna. Lublin: Wydawnictwo KUL, 2018.

SŁomKa, Marek. Ewolucjonizm chrześcijański o pochodzeniu człowieka. Lublin: Gaudium, 2004.

SŁoмKA, Marek. „Antynaukowy kreacjonizm jako negacja teistycznego ewolucjonizmu”. W: Naukowy a religijny obraz poczatku wszechświata i czlowieka. Perspektywy dialogu, red. Jacek Golbiak, Karol Jasiński, Wojciech Kotowicz, 113-124. Olsztyn: Wydawnictwo UWM, 2015.

SowA, Łukasz. „Wpływ teorii ewolucji Karola Darwina na moralność, życie i pojmowanie świata". Communitas 30, $\mathrm{nr} 1$ (2008): 48-51.

Stancel, Stanisław, Lucjan Balter, Kazimierz Czulak, Paweł GóralczyK, red. Kosmos $i$ człowiek. Poznań: Pallottinum, 1989.

Strus, Robert, Wiesław Galant, red. Świadczę o Jezusie w świecie (Podręcznik do nauki religii dla II klasy szkół ponadgimnazjalnych). Lublin: Gaudium, 2013.

SzPet, Jan, Danuta JACKOwIAK, red. Moje miejsce $w$ świecie (Podręcznik do nauki religii dla II klasy szkół ponadgimnazjalnych). Poznań: Wydawnictwo św. Wojciecha, 2013.

SzYMANIAK, Marcin. „Maciej Giertych chce wyrzucić ewolucję ze szkół”. Życie Warszawy, 12.10.2006. Dostęp 17.08.2020. http://www.zw.com.pl/artykul/192900.html.

Teerikorpi, Pekka, Mauri Valtonen, Kirsi Lehto, Harry Lehto, Gene Byrd, Arthur Chernin. The Evolving Universe and the Origin of Life. The Search for Our Cosmic Roots. New York: Springer, 2009.

TUREK, Józef. „Wszechświat czasowo nieskończony i stworzony”. Studia Warmińskie 28 (1991): $217-233$.

„UW: teoria ewolucji jest powszechnie uznawana”. Wirtualna Polska, 19.10.2006. Dostęp 20.08. 2020. https://wiadomosci.wp.pl/uw-teoria-ewolucji-jest-powszechnie-uznawana-6037394 $343776897 \mathrm{a}$

Van Inwagen, Peter. „Księga Rodzaju a ewolucja”. Tłum. Marcin Iwanicki, Marek Osmański. Roczniki Filozoficzne 52, nr 1 (2004): 363-398.

VIA, Sara. „Natural selection in action during speciation”. Proceedings of the National Academy of Sciences of the United States of America 106 (2009): 9939-9946 (suplement 1).

„Wiedza kontra ignorancja”. Sprawy Nauki, 9.11.2006. Dostęp 2.09.2020. http://www.sprawy nauki.edu.pl/archiwum/dzialy-wyd-papierowe/197-naukowa-agora/212-149. 
Yockey, Hubert P. Information Theory, Evolution and the Origin of Life. Cambridge: CUP, 2005.

Zon, Józef. „Ewolucja i ewolucjonizm”. W: Dydaktyka filozofii, t. 7, Filozofia przyrody, red. Stanisław Janeczek, Anna Starościc, Dariusz Dąbek, Justyna Herda, 87-113. Lublin: Wydawnictwo KUL, 2013.

Zon, Józef, Zuzanna KieroŃ. „Człowiek jako wytwór ewolucji”. W: Dusza-Umyst-Ciało. Spór o jedność bytowa człowieka, red. Andrzej Maryniarczyk, Katarzyna Stępień, 163-178. Lublin: Polskie Towarzystwo Tomasza z Akwinu, 2007.

ŻyciŃski, Józef. Bóg i stworzenie. Zarys teorii ewolucji. Lublin: Gaudium, 2011.

\section{ANTYEWOLUCYJNY KREACJONIZM WE WSPÓŁCZESNEJ POLSCE I JEGO WPŁYW NA EDUKACJĘ RELIGIJNĄ}

\section{Streszczenie}

W niniejszym tekście analizuję tezy stawiane przez polskich antyewolucyjnych kreacjonistów, które w ostatnich latach zostały wyrażone nie tylko w publikacjach naukowych, ale także w ramach różnych form przekazu treści wiary religijnej oraz w publicznie prowadzonych dyskusjach, stanowiących istotny aspekt omawianej dziedziny. Celem artykułu jest określenie głównych składowych antyewolucyjnego kreacjonizmu oraz uchwycenie mechanizmów myślenia, które prowadzą do wewnętrznej niespójności formułowanych koncepcji a także niezgodności z wiedzą przyrodniczą, filozoficzną i teologiczną.

Pokazuję jak wiele aspektów antyewolucyjnego kreacjonizmu zostało włączonych do podręczników katechetycznych, opublikowanych w ostatniej dekadzie w Polsce. Stanowczo za dużo jest tam treści zawierających podstawowe błędy i zredagowanych w taki sposób, który nie służy budowaniu relacji między nauką a wiarą religijną. Ewolucjonizm kojarzony jest głównie ze skrajnym naturalizmem, zaś kreacjonizm z fundamentalistyczną interpretacją biblijnych opisów stworzenia i odrzucaniem teorii ewolucji. Zbyt mało uwagi zwraca się na naukowe postacie ewolucjonizmu oraz wartościowe nurty kreacjonizmu. Wynika to między innymi z braku konsultacji treści na stylu nauk przyrodniczych i teologii z tymi reprezentantami Kościoła katolickiego, którzy akademicko zajmują się problematyką interdyscyplinarną.

Słowa kluczowe: kreacjonizm; ewolucjonizm; nauki przyrodnicze; religia; edukacja.

\section{ANTI-EVOLUTIONARY CREATIONISM IN CONTEMPORARY POLAND AND ITS INFLUENCE ON RELIGIOUS EDUCATION}

\section{S u m m a ry}

In this text, I analyze the theses put forward by Polish anti-evolutionary creationists, which in recent years have been expressed not only in scientific publications, but also in various forms of transmitting the content of religious faith and in public debates, which are an important aspect of the discussed field. The aim of the article is to define the main components of anti-evolutionary creationism and to capture the ways of thinking that lead to internal inconsistency of formulated concepts as well as their incoherence with philosophical, theological, and scientific knowledge.

I show how many aspects of anti-evolutionary creationism have been included in catechetical books published in the last decade in Poland. There are too many fundamental errors in their content that is often edited in a manner that does not serve to build a positive relationship between science and religious faith. Evolutionism is mainly associated with extreme naturalism, and 
creationism with a fundamentalist interpretation of the biblical accounts of creation and the rejection of the theory of evolution. Too little attention is paid to the scientific forms of evolutionism and the worthwhile currents of creationism. It results, among other things, from the lack of consultation of the problems that lie on the frontier between natural sciences and theology with those representatives of the Catholic Church who deal with interdisciplinary issues in daily academic practice.

Keywords: creationism; evolutionism; natural sciences; religion; education. 